\title{
26. ALBIAN TO SENONIAN PALYNOLOGY OF SITE 364, ANGOLA BASIN
}

\author{
Roger Morgan, Geological and Mining Museum, 36-64 George Street North, Sydney, New South Wales, Australia
}

\begin{abstract}
Palynological processing of 19 samples from Site 364 yielded 11 good assemblages. The frequent spores and pollen provide better biostratigraphic data than the useful, but rare, dinoflagellates. Cores $42-46$ are considered early Albian, Cores $38-40$ middle Albian, Cores 29-32 late Albian, Core 27 Vraconian or Cenomanian, and Cores 23-25 late Turonian to Coniacian, with many reworked Cenomanian-Turonian elements.

The site was located a considerable distance from shore during the Cretaceous, or lacked large runoff from major river systems, as most spores and pollen are windborne. The climate may have been tropical but semi-arid; the vegetation was certainly very different from that at Site 361. Although restricted, marine influence in the form of dinoflagellates existed from the south.
\end{abstract}

\section{INTRODUCTION}

This shore based post-leg study was undertaken at the Geological Survey of New South Wales, on samples supplied by Dr. W. Siesser, of the University of Cape Town, and the Lamont-Doherty sample repository. The aim was to improve the age dating of those periods when the basin was restricted and open marine faunas poor. Palynological analysis is largely restricted to sapropelic lithologies, with four exceptions from gray marly shale. Nineteen samples were studied from 15 cores in the Cretaceous part of the section. Four were completely barren, and a further four yielded poor assemblages. Palynomorph distribution is presented in Table 1.

\section{GEOLOGICAL BACKGROUND}

Site 364 penetrated a Pleistocene to Albian sequence with a probable Cenomanian-early Turonian hiatus (Chapter 4, this volume). The original target for the hole, late Aptian salts underlying much of the Angola Basin, was not reached and the hole at total depth was in early Albian or possibly late Aptian sediments.

The early and partly middle Albian interbedded dolomite and sapropelic mudstones are interpreted to represent cyclic restrictions of the basin. At this time Africa and South America were adjacent, and the basin was restricted by the Walvis Ridge (Figure 1). The middle Albian to possibly Cenomanian limestones and marly limestones represent a period of continuous shallow open marine conditions. In the Turonian and lower Senonian, lithologies deposited include chalks, marly chalks, and sapropelic mudstones, indicating a second period of cyclic restriction. Middle Senonian to Eocene nanno and marly chalk represent open marine to deep-sea conditions, after the final separation of Africa and South America and perhaps subsidence of the Walvis Ridge. Miocene to Pleistocene lithologies are typical of the deep-sea conditions prevailing to this day at Site 364.

\section{PALYNOLOGICAL BACKGROUND}

Although no established zonations exist in the literature for areas immediately surrounding Site 364, a number of zonations from areas to the north have proved useful. Jardine and Magloire (1965) erected 12 spore pollen zones ranging in age from Barremian to Maestrichtian. This zonation was established in Senegal and the Ivory Coast, over $3000 \mathrm{~km}$ and $20^{\circ}$ of latitude away. Muller (1966) erected five zones of Albian to Senonian age from the Maranhas, Bahia, Sergipe, and Alagoas basins of coastal Brazil. Herngreen $(1973,1975)$ erected three zones and six subzones in the early Albian to late Cenomanian of the Barreirinhas Basin and discussed the Cenomanian to lower Senonian of the Sergipe Basin, both of coastal Brazil. Before the drifting apart of Africa and South America, the Sergipe Basin was within $1000 \mathrm{~km}$ and $5^{\circ}$ of latitude of Site 364. In Cenomanian time, separation was about $1500 \mathrm{~km}$ and increasing rapidly.

These spore-pollen zonations were expected to be of limited use at Site 364, with vegetation changes associated with latitudinal climatic difference being reflected in the spore pollen floras. The South American zonations were expected to be useful in the Early Cretaceous, but of decreasing relevance in the Late Cretaceous, as the South Atlantic Ocean widened.

A compilation from the zonations cited is presented in Figure 2, with additional data from Jardine (1967), Boltenhagen (1965, 1967, 1975), Jardine et al. (1974), and Brenner (in press). Total known ranges are shown, although some palynomorphs are known to be facies dependent. In particular, Elaterosporites spp. and Cretaceiporites spp. do not have the maximum known range at Site 364 . Some inaccuracy may have been introduced into Figure 2 as spore pollen taxa, some facies controlled, were used to correlate the zonations. 
TABLE 1

Palynomorph Distribution Chart

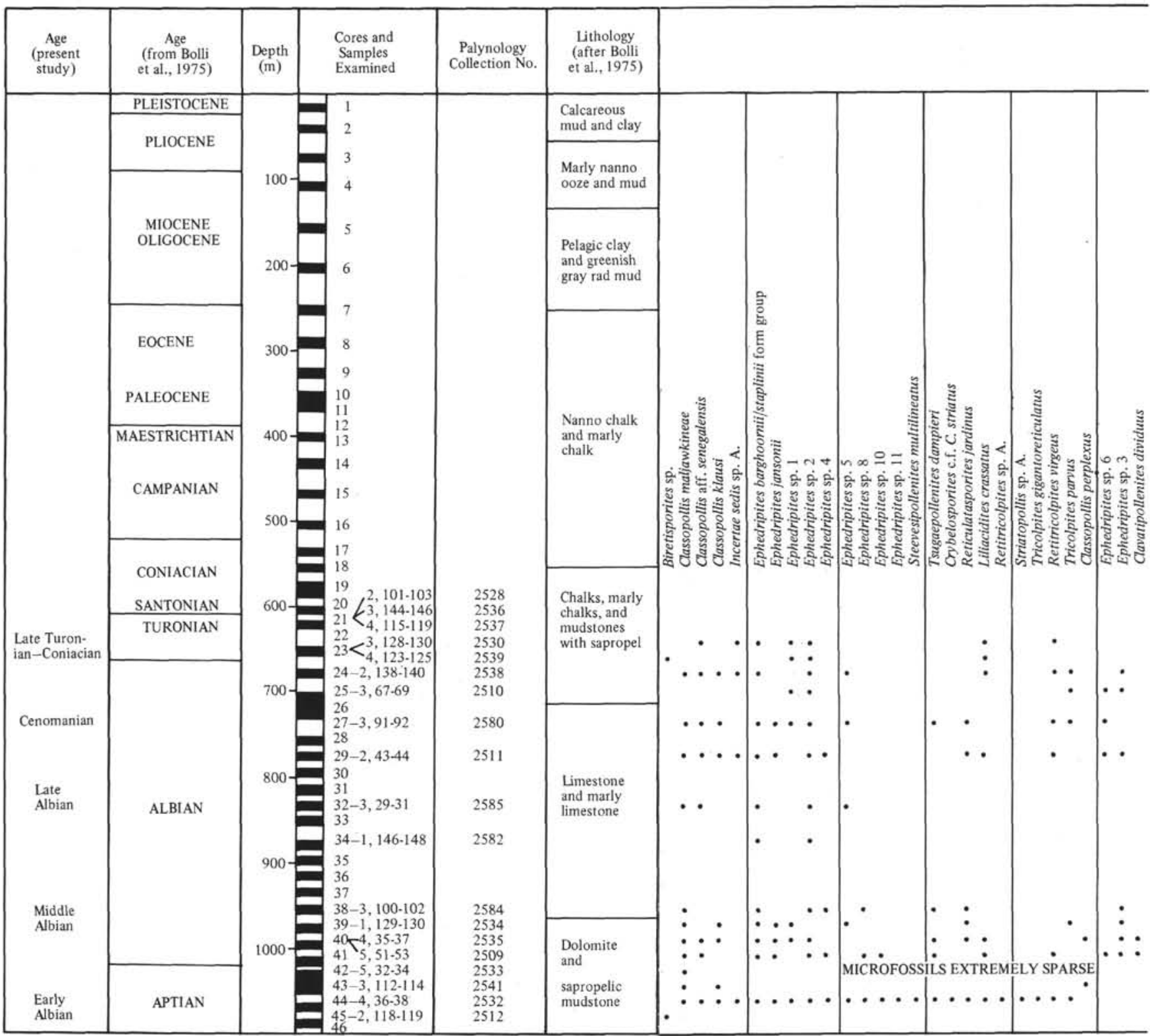

As the spore pollen zonations are based on largely non-marine deposits, little attention has been paid to the associated dinoflagellates. Only Herngreen (1975) has discussed upper Senonian dinoflagellates as biostratigraphic markers.

The age of the palynological zones rests on somewhat contradictory evidence, chiefly from microfaunas. Jardine and Magloire (1965) rely on foraminifer and megafaunal evidence which they discuss in detail. Muller (1966) and Herngreen (1973) rely on unpublished foraminifer evidence, but Herngreen (1975) includes discussion of megafaunas and foraminifers. The ages used here are shown on Figure 2, and are only a compilation of the other authors, and should be used with caution. Errors in correlation of the zonations, caused by facies control of the spores and pollen, may also make the ages less precise.

\section{BIOSTRATIGRAPHIC ANALYSIS}

Cores 42 to 46 are considered early Albian, Cores 3840 middle Albian, Cores 29-32 late Albian, Core 27 Vraconian or Cenomanian, and Cores 23-25 late Turonian to Coniacian.

Greatest similarity over the whole section is with the zonation of Jardine and Magloire (1965), and so samples are assigned to those zones Figure 2 shows the correlated zones of the other authors.

Core 46-I did not examine this core, but S. Jardine (personal communication) has observed dinoflagellate species typical of the early Albian (Madiela Series) of the Gabon and Congo basins.

Core 45-Only few nondiagnostic pollen were observed. S. Jardine (personal communication) observed a nondiagnostic assemblage of spores and 


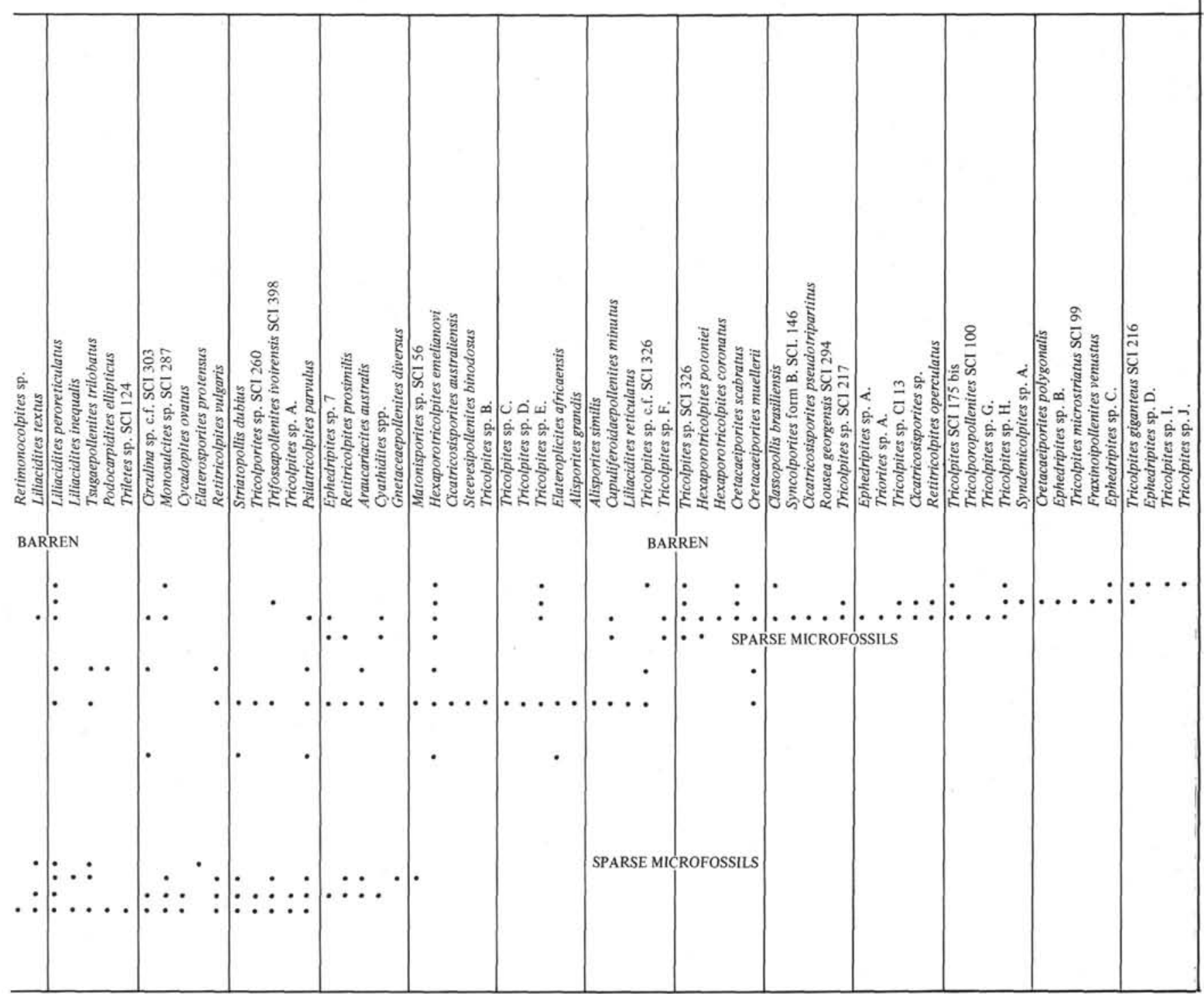

pollen lacking dinoflagellates. He considered Cores 45 and 46 to represent assemblages known from the postsalt deposits of the Congo and Gabon basins dated as early Albian.

Core 44-Ephedroid and gymnospermous (Classopollis) pollen dominate, with rare spores, and monocolpate and tricolpate angiospermous pollen. This assemblage is assigned to the late Aptian and early Albian Zone XI of Jardine and Magloire. The presence of Crybelosporites $\mathrm{cf}$. C. striatus prevents assignment to Zone XII, and the absence of Striatopollis dubius prevents assignment to Zone $X$.

The angiosperm pollen consists of three monocolpate and five tricolpate species. The oldest records of monocolpate pollen are the Barremian to Aptian of Israel (Brenner, personal communication), and Patagonia (Archangelsky and Gamerro, 1967). The oldest records of tricolpate pollen are the late Aptian to early Albian of Israel (Brenner, personal communication) and the Aptian of Brazil (Muller, 1966). As these areas were at similar latitudes in the Cretaceous, they may be expected to provide relevant age evidence. At these levels, however, tricolpate pollen are simply ornamented, reticulate or scabrate, and so the complexity and diversity of the tricolpate pollen in Core 44 would be unique if the core was Aptian in age. An early Albian age is favored for Core 44, considered in conjunction with the middle Albian age of Cores 3840. The dinoflagellates are not useful age indicators.

Cores 42, 43-Assemblages are too poor to date, although study of additional material may give representative microfloras.

Cores 38, 39, 40-Classopollis dominates, with secondary abundances of Ephedripites, tricolpates, Trifossapollenites, and monocolpates. Spores are absent. Except for this feature, a Zone $\mathrm{X}$ assignment is 
TABLE 1 - Continued

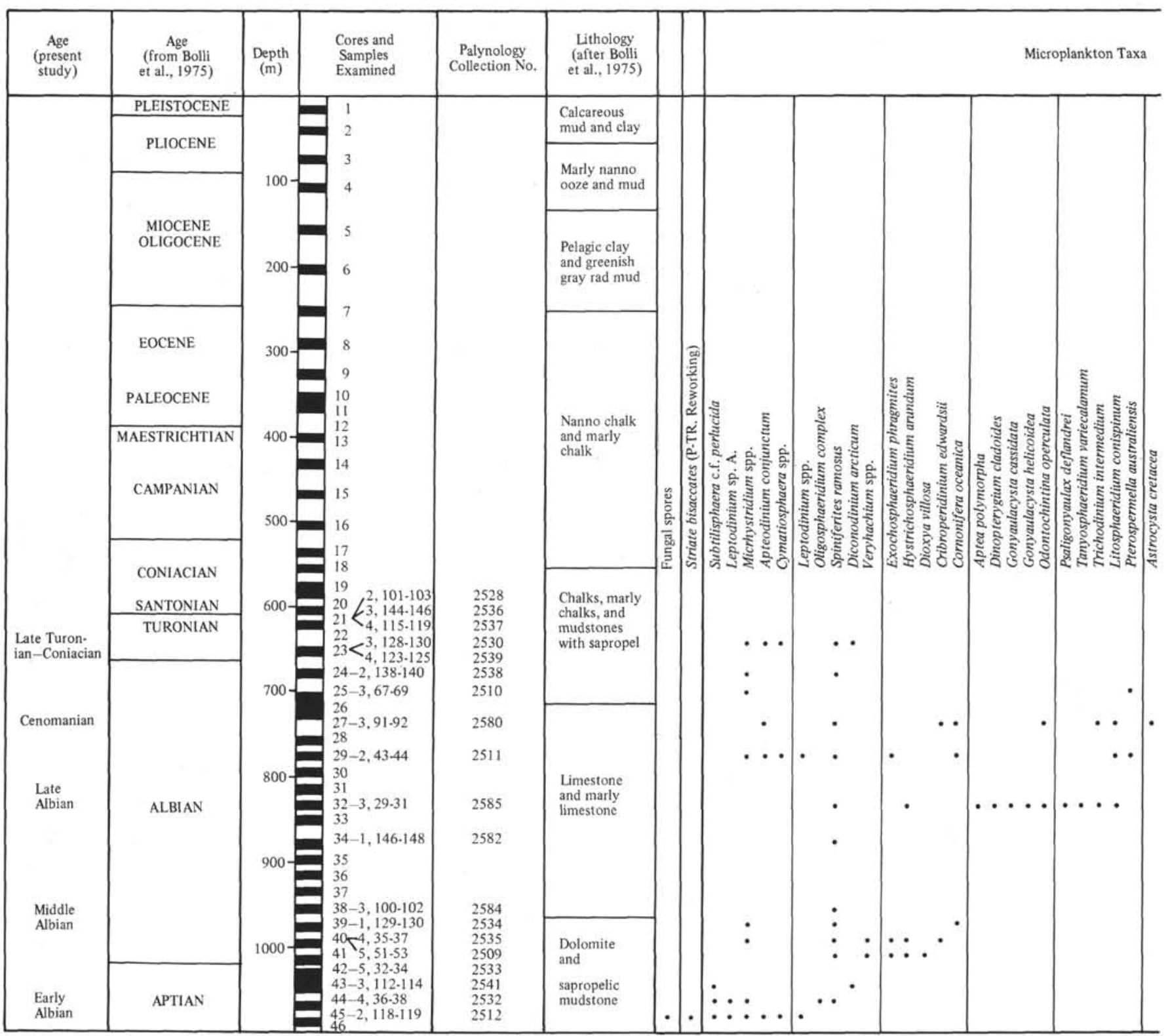

suggested. The presence of Striatopollis dubius (Cores 39, 40), Tricolporites S. CI. 260 (Cores 39, 40), and Elaterosporites protensus (Core 38 ) indicate a middle Albian Zone X or younger assignment. Jardine (1967) dates the oldest occurrence of $S$. dubius as within the middle Albian on foraminifer evidence.

Dinoflagellates from Cores 39, 40 include Hystrichosphaeridium arundum, recorded from the early to late Albian (pre-Vraconian) in Europe and elsewhere (Verdier, 1975) and Dioxya villosa, recorded from Australia in the middle and late Albian (unpublished information). Thus both spore-pollen and dinoflagellate evidence support a middle Albian age.

Core 34-The assemblage is too poor to date.

Cores 29, 32-Classopollis and Ephedripites dominate, with secondary abundances of tricolplates and Trifossapollenites. Spores and bisaccate pollen are rare. Except for the scarcity of spores, the assemblage is similar to Zones VIII, IX, and X. The presence of $S$. dubius (Cores 29, 32) indicates assignment to the lower Zone VIII or older zones. The presence of Hexaporotricolpites emelianovi (Cores 29, 32), Elateroplicites africaensis forma B (Core 32), Elateroplicites africaensis forma A (Core 29), and Cretaceiporites muellerii (Cores 29, 32) indicate assignment to the lower Zone VIII or younger zone. Thus these cores are assigned to the late Albian lower Zone VIII of Jardine and Magloire.

Dinoflagellates include $H$. arundum (Core 32-late Albian and older), L. conispinum (Cores 29, 32-late Albian and younger), and $P$. deflandrei (Core 32-late Albian and younger). The ranges are detailed by Verdier (1975), and indicate a late Albian age, in agreement with the spore-pollen data.

Core 27-Classopollis and Ephedripites dominate, with secondary abundance of tricolpates and 
TABLE 1 - Continued

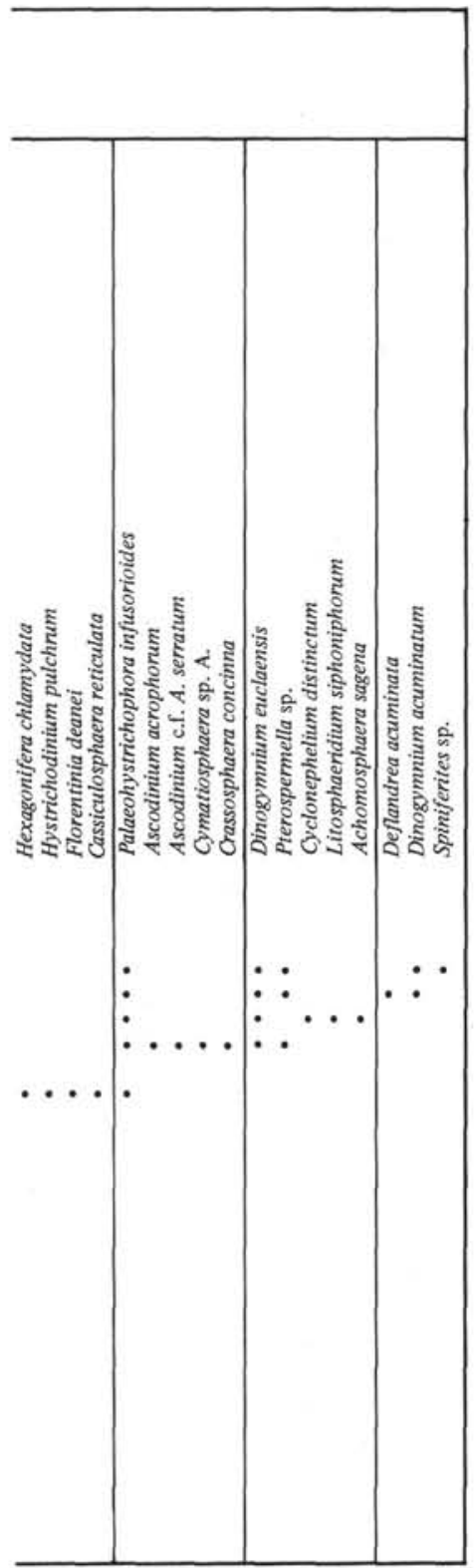

Trifossapollenites. Spores are rare. Except for this, the assemblage is similar to Zones VIII, IX, and X. The presence of Reticulatasporites jardinus suggests a Zone VIII or older assignment. The presence of $H$. emelianovi suggests a Zone VIII or younger assignment. The absence of $S$. dubius may suggest that an early Cenomanian upper Zone VIII assignment is more likely.

Dinoflagellates include $P$. infusorioides, recorded from Vraconian and younger sediments (Verdier, 1975).

Thus spore pollen data and dinoflagellate data indicate a Vraconian or early Cenomanian age, with the Cenomanian age favored by negative evidence.

Cores 23, 24, 25-Poorly ornamented small and giant tricolpate pollen dominate, with secondary abundance of Ephedripites, Cretaceiporites, and Hexaporo tricolpites. This assemblage resembles the Turonian to early Senoian (Zone VII of Jardine and
Magloire. Problems exist, however, in the mutual occurrence of species recorded in the literature as mutually exclusive. The younger elements which are considered to be in situ include:

Coniacian-Maestrichtian-Tricolpites S.CI. 326 (Cores 23, 24, 25)

Coniacian-Santonian-Syncolporites S.CI. 146 (Core 24)

Turonian-Coniacian-Rousea S.CI. 294 (Core 24)

Turonian-Coniacian-Tricolpites S.CI. 217 (Cores $23,24)$

Turonian-Coniacian-Tricolpites S.CI. 13 (Cores 23, 24)

Turonian-Coniacian-Tricolpites S.CI. 100 (Core 24)

Turonian-Coniacian-Tricolpites giganteus (Core 23)

Turonian-Tricolpites S.CI. 99 (Core 23)

This group suggests a Turonian-Coniacian age as probable. Older elements considered to be reworked include:

Cenomanian-Hexaporotricolpites potoniei (Cores 24,25 )

Jurassic to late Cenomanian-Classopollis spp. (Cores 23, 24)

Early to late Cenomanian-Classopollis brasiliensis (Core 23)

Late Cenomanian-Tricolpites S.CI. 175 bis (Core 24)

This group suggests that Cenomanian sediments were present in the area, and have been reworked during the Turonian-Coniacian.

Dinoflagellates from these samples show similar mixing suggesting Coniacian or younger sediments, with Cenomanian-Turonian reworking. Significant species include Dinogymnium euclaensis (Cores 23, 24, 25, Senonian to Maestrichtian, worldwide), Dinogymnium acuminatum (Core 23, Senonian to Maestrichtian, worldwide), Deflandrea acuminata (Core 23, Cenomanian to Turonian, worldwide), and Ascodinium acrophorum (Core 25, Cenomanian, Australia). The first two or possibly three species are considered in situ, and the last one or possibly two reworked.

In the Northern Hemisphere, the Dinogymnium species listed are considered to be SantonianMaestrichtian indicators, although the genus has been recorded sporadically from the Turonian, and rarely from the Cenomanian. S. Jardine (personal communication) has found these Dinogymnium species in African sediments older than Santonian. The dinoflagellates thus suggest an early Senonian or younger age with Cenomanian-Turonian reworking.

In synthesis, the combined spore-pollen and dinoflagellate evidence favor a Turonian-Coniacian age, with Cenomanian and Turonian reworking.

\section{PALEOENVIRONMENT}

Environmental conclusions from the present study are automatically limited because only sapropelic lithologies provided good assemblages. In a cyclicly restricted environment such as this, palynology can thus only provide insight to the most restricted phases.

General features of the organic content of these cores suggest a very low energy environment of deposition, at 


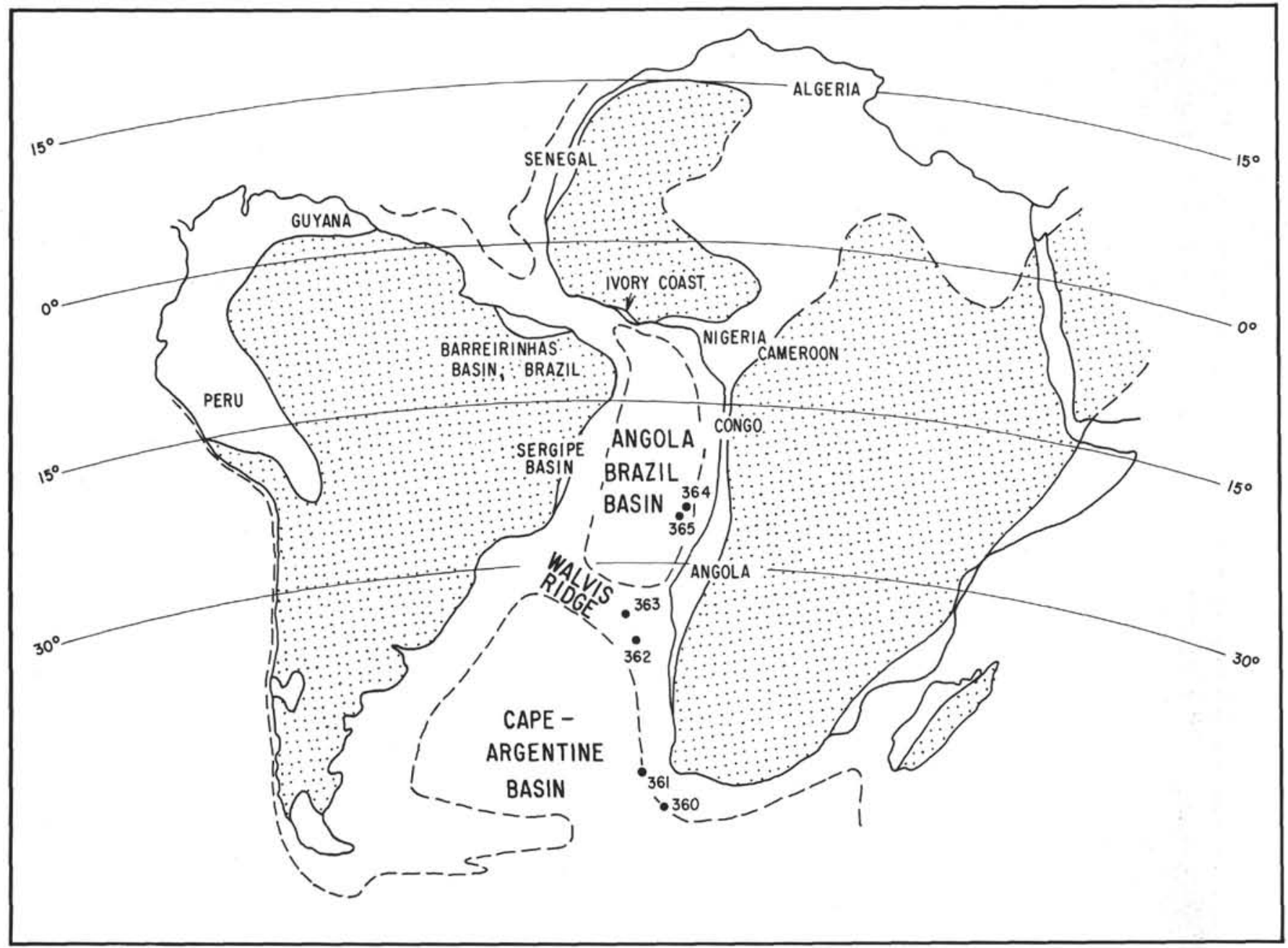

Figure 1. Locality map in middle cretaceous time (after Jardine et al. 1974) onshore sedimentation largely non-marine.

some distance from shore, with dominant wind transport of spores and pollen. Organic detritus, other than spores and pollen, is $1-2 \mu \mathrm{m}$ in size, reflecting the very low energy of the environment, sufficient to allow settling of these particles. The energy is so low that the spores and pollen cannot easily have been transported into the site by water currents, especially as organic debris intermediate in size between the pollen and the fine matter is absent. Some samples have abundant fine matter, but are barren of spores and pollen, while others have diverse microfloras as well as abundant fine matter. This is interpreted as reflecting fluctuating wind patterns, alternately denying and supplying spores and pollen to Site 364 . The absence of cuticle and wood tracheid fragments also suggests distance from shore, away from the influence of major river systems and water borne detritus. The only exception is in Core 45 , where Permian or Triassic pollen, presumably reworked by eroding rivers from the hinterland, are found.

The average spore-pollen diversity of about 30 species suggests a stable and homogeneous plant community, possibly living under harsh conditions. Under more favorable conditions, diversity might average 50 species, but the observed diversity may be biased against large and heavy spores and pollen incapable of transport to Site 364 by wind currents.

The taxonomic composition suggests a tropical, possibly hot and semiarid climate, away from deltaic influence. The overall nature of the assemblages, as well as the occurrence of many zonal indicators, shows close affinity with the paleo-equatorial microfloras of Jardine and Magloire. Sufficient differences indicate that the floras, separated by $20^{\circ}$ of palaeolatitude, are not, however, identical. A tropical influence is further suggested by the presence of early Albian tricolpate angiosperms, which do not appear in temperate regions until the middle or late Albian. The dominance of ephedroid, cycadophyte, angiosperm, and Classopollis pollen, with rare pteridophyte and very rare bisaccate pollen implies hot semi-arid conditions. These features and the presence of certain exotic spores and pollen suggest affinity with the tropical Northern Gondwana Province of Brenner (in press), rather than the temperate Southern Gondwana Province, which is characterized by persistent bisaccate and minor ephedroid pollen, as seen at Site 361 by McLachlan and Pieterse (this volume). The Northern Gondwana Province of Brenner (in press) is essentially the same as the African-South American microfloral belt of 


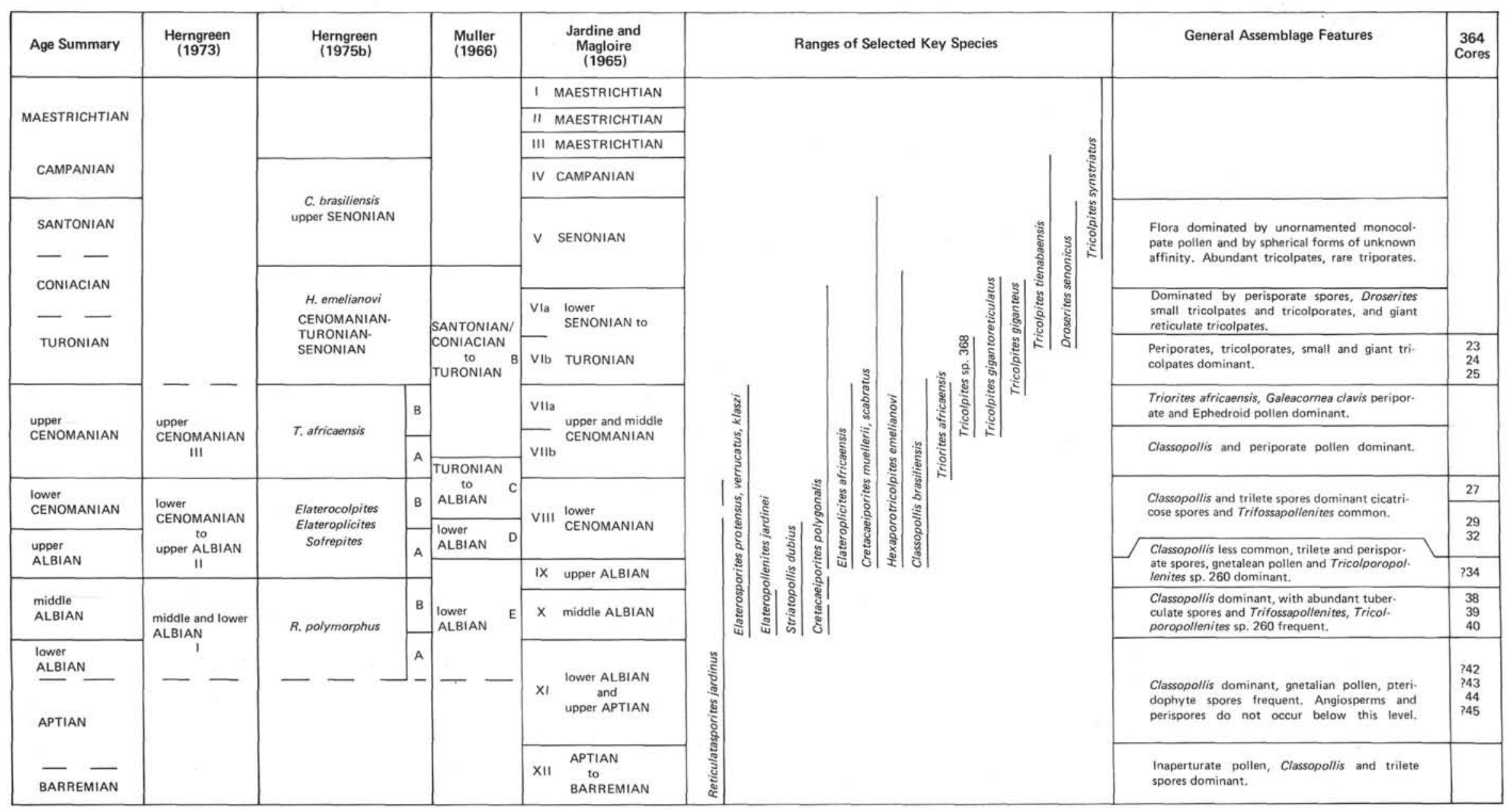

Figure 2. Compilation of relevant biostratigraphic data. 
Herngreen (1975), which occupies a band of approximate $15^{\circ}$ of latitude both sides of the paleoequator. The virtual absence of the large and exotic spores and pollen common in deltas suggests the absence of these depositional features, or their distant presence.

The microplankton suggest restricted marine deposition with possible southern (Austral) influence. Low diversity of dinoflagellate assemblages (an average of 10 species), and frequent common acritarchs indicate a restricted marine influence. Of the dinoflagellates observed and previously described, all occur in sediments of similar age in Australia, although many occur worldwide. Tropical dinoflagellate assemblages in the Lower Cretaceous are poorly known, but none of the Aptian species described by Jain and Millepied from Senegal were observed. Dioxya villosa, in the Albian, and Ascodinium acrophorum reworked into the Turonian-Coniacian, are recorded here for the first time outside Australia, and may indicate a southern (Austral) influence.

\section{TAXONOMIC LIST}

The following list is a key to the taxonomy used. Reference to the original author is made to those forms adequately described in the literature. There are inconsistencies in the taxonomy of the spores and pollen at the generic level because of the use of the published informal names of Jardine and Magloire (1965). For future recognition, previously unrecorded species are informally designated, briefly described, and illustrated.

\section{Spores}

Biretisporites sp. small smooth-walled rounded triangular amb. Cicatricosisporites australiensis Cookson, 1953

Cicatricosisporites pseudotripartitus (Bolkhovitina, 1961) Dettman, 1963 (pl. 1, fig. 1)

Cieatricosisporites sp. -3 (or rarely 4 ) distal muri, about $5 \mu \mathrm{m}$ wide, with lumina $1 \mu \mathrm{m}$ wide, in each series; strong membranous lips (3$4 \mu \mathrm{m}$ high); contact area smooth.

Crybelosporites cf. C. striatus (Cookson and Dettman, 1958) Dettmann, 1963-this spore differs from C. striatus by being irregularly rugulate instead of being regularly reticulate.

Cyathidites sp. psilate forms with concave triangular amb.

Elaterosporites protensus (Stover) Jardine, 1967

Matonisporites sp. S.CI. 56 Jardine and Magloire, 1965.

\section{Inaperturate Forms}

Araucariacites australis Cookson, 1953.

Circulina? sp. S.CI. 303 Jardine and Magloire, 1965 (pl. 1, fig. 2, 3).

Classopollis maljawkineae Boltenhagen, 1973 (pl. 1, fig. 4).

Classopollis aff. senegalensis Reyre, et al., 1970, in Boltenhagen, 1973 (pl. 1, fig. 6, 7).

Classopollis klausi Boltenhagen, 1973 (pl. 1, fig. 8).

Classopollis perplexus Boltenhagen, 1973 (pl. 1, fig. 5)

Classopollis brasiliensis Herngreen, 1975-includes Classopollis sp. S.CI. 310 Jardine and Magloire, 1965 (pl. 1, fig. 9).

Cycadopites ovatus Rouse, 1959 (pl. 1, fig. 10).

Monosulcites sp. S.CI. 287 Jardine and Magloire, 1965 (pl. 1, fig. 13).

Tsugaepollenites dampieri (Balme) (pl. 1, fig. 12).

Tsugaepollenites trilobatus (Balme) (pl. 1, fig. 11).

\section{Polyplicate Pollen}

Elateroplicites africaensis Herngreen, 1973 (pl. 2, fig. 1, 2).

Ephedripites barghoormii/staplinii form-group (Pocock, 1964) (pl. 2, fig. 3).

Ephedripites jansonii (Pocock, 1964), Muller, 1968 (pl. 2, fig. 4).

Ephedripites sp. 1 Herngreen, 1973-larger than $50 \mu \mathrm{m}$, with many narrow ridges; similar to Ephedripites sp. S.CI. 284 Jardine and Magloire, 1965. (pl. 2, fig. 5, 8).
Ephedripites sp. 2 Herngreen, 1973-20-50 $\mu \mathrm{m}$ long with many narrow ridges (pl. 2, fig. 7,9).

Ephedripites sp. 3 Herngreen, 1973-less than $20 \mu \mathrm{m}$ long with many narrow ridges (pl. 3, fig. 2, 7).

Ephedripites sp. 4 Herngreen, 1973-larger than $50 \mu \mathrm{m}$ with fewer broad ridges; very large specimens are similar to Ephedripites $\mathrm{sp}$. S.CI. 391 Jardine and Magloire, 1965.

Ephedripites sp. 5 Herngreen, $1973-20-50 \mu \mathrm{m}$ long with broad ridges (pl. 2, fig. 6).

Ephedripites sp. 6 Herngreen, 1973-smaller than $20 \mu \mathrm{m}$, with broad ridges.

Ephedripites sp. 7 Herngreen, 1973-larger than $50 \mu \mathrm{m}$ with numerous ridges of narrow to moderate width; exine thick and solid at the poles; similar to specimen figured by Stover (1964, pl. 2, fig. 10).

Ephedripites sp. 8 Herngreen, 1973-larger than $50 \mu \mathrm{m}$; about six very broad spiral ridges.

Ephedripites sp. 10 Herngreen, 1973-20-50 $\mu \mathrm{m}$ long; about six or seven very broad weakly spiral ridges; similar to pl. 3 fig. 16, 17 of Jardine and Magloire (1965) as Cicatricosisporites S.CI. 164B.

Ephedripites sp. 11 Herngreen, 1973-larger than $50 \mu \mathrm{m}$, about 8-10 broad weakly spiral ridges which are separated except at the poles.

Gnetaceaepollenites diversus Stover, 1964 (pl. 3, fig. 1).

Steevesipollenites binodosus Stover, 1964 (pl. 3, fig. 3).

Steevesipollenites multilineatus Stover, 1964-over $50 \mu \mathrm{m}$ long; (pl. 3, fig. 4) many (30-40) narrow ridges; distinctive polar "granular caps."

Ephedripites sp. A-less than $20 \mu \mathrm{m}$ long; small solid thickening at poles; about 10 broad straight margined ridges with about 12 cross-striations on each ridge.

Ephedripites sp. B-20-50 $\mu \mathrm{m}$ long, with solid polar thickenings and with 8-10 broad wavy edged ridges (pl. 3, fig. 6, 8).

Ephedripites sp. C $-20-50 \mu \mathrm{m}$ long with 6-8 broad wavy edged spiral ridges (pl. 3 , fig. 5).

\section{Bisaccate Pollen}

Alisporites grandis (Cookson, 1953) Dettman, 1963.

Alisporites similis (Balme, 1957) Dettman, 1963.

Podocarpidites ellipticus Cookson, 1947.

\section{Tricolpate Pollen}

Cupuliferoidaepollenites minutus (Brenner, 1963) Norris, 1967 (pl. 4, fig. 1).

Fraxinoipollenites venustus Singh, 1971 (pl. 4, fig. 2).

Psilatricolpites parvulus (Groot and Penny, 1960) Norris, 1967 (pl. 4, fig. 3-5).

Retitricolpites sp. A-prolate, equatorial diameter $26 \mu \mathrm{m}$; exine distinctly thickened at poles; fine $0.5 \mu \mathrm{m}$, even reticulation does not cover poles; colpi long (pl. 4, fig. 6).

Retitricolpites operculatus Herngreen (pl, 4, fig. 7).

Retitricolpites prosimilis Norris, 1967.

Retitricolpites virgeus (Groot, et al., 1961) Brenner, 1963 (pl. 4, fig. 8-10).

Retitricolpites vulgaris Pierce; 1961 (pl. 4, fig. 11-13).

Rousea georgensis (Brenner, 1963) Dettman, 1973.

Striatopollis sp. A-prolate, equatorial diameter $32 \mu \mathrm{m}$ fine low surface muri in fine discontinuous striate and reticulate pattern; densely infrabaculate (pl. 4, fig. 14, 15).

Striatopollis dubius Jardine and Magloire 1965-here restricted to specimens illustrated in pl. 10 fig. 50-51 of Jardine and Magloire, showing equatorial, not longitudinal, striation at the equator. (pl. 5, fig. 1, 2).

Tricolpites giganteus Jardine and Magloire 1965.

Tricolpites gigantoreticulatus Jardine and Magloire 1965 (pl. 5, fig. 3).

Tricolpites microstriatus Jardine and Magloire 1965.

Tricolpites parvus Stanley 1965 (pl. 5, fig. 4, 5, 12).

Tricolpites sp. S.CI. 175 bis Jardine and Magloire 1965-subspherical, subcircular amb; equatorial diameter 35-40 microns; colpi long, exine thin, finely granulate and very finely infrabaculate; differs from Tricolpites $\mathrm{sp} . \mathrm{F}$ by having a thinner wall and longer colpi. (pl. 5, fig. 8).

Tricolpites sp. S.CI. 260 Jardine and Magloire 1965 (pl. 5, fig. 10, 11).

Tricolpites sp. CI. 13 Jardine and Magloire 1965 (pl. 5, fig. 7). 
Tricolpites sp. S.Cl. 217 Jardine and Magloire 1965.

Tricolpites sp. cf. T. sp. S.CI. 326 Jardine and Magloire 1965-oblate, convex triangular amb; equatorial diameter 17 microns; colpi long, exine thin, covered with low verrucae $0.6-1.0$ microns in diameter; differs from $T$. sp. 326 by having longer colpi, less pronounced ornament, and by being smaller. (pl. 5, fig. 6).

Tricolpites sp. S.CI. 326 Jardine and Magloire 1965-subspherical, equatorial diameter 28 microns; colpi short to moderate length; exine 1 micron thick, densely covered with verrucae 1 micron in diameter. (pl. 5, figs. 13, 14).

Tricolpites sp. C. —oblate triangular amb; equatorial diameter $17 \mu \mathrm{m}$; colpi extend three quarters of the way to the poles; exine $1.0 \mu \mathrm{m}$, with verrucae $0.5-1.0 \mu \mathrm{m}$ in diameter; triangular amb, verrucate ornament, andlon colpiare diagnostic (pl. 6, fig. 3,4).

Tricolpites sp. B-oblate, rounded triangular to sub-circular amb; equatorial diameter 20 microns; exine thin, smooth, layering not observed; colpi extend almost to the poles, Tricolpites CI. 13 is similar, but the colpi do not extend as close to the poles; subcircular amb and very long colpi are diagnostic (pl. 6, fig. 7).

Tricolpites sp.C-oblate triangular amb; equatorial diameter $17 \mu \mathrm{m}$; colp extend three quarters of the way to the poles; exine $1.0 \mu \mathrm{m}$ thick, with verrucae $0.5-1.0 \mu \mathrm{m}$ in diameter; triangular amb, verrucate ornament, and long colpi are diagnostic (pl. 6, fig. 8).

Tricolpites sp. D-subspherical to slightly prolate; equatorial diameter 25-30 $\mu \mathrm{m}$; colpi long; exine reticulate with bimodal lumina (0.5-1.0 and $2.5 \mu \mathrm{m}$ diameter), large lumina in interradial equatorial area; bimodal reticulum is diagnostic (pl. 6, fig. 3,4).

Tricolpites sp. E-oblate, convexly triangular amb; equatorial diameter $2 \mu \mathrm{m}$; colpi short, exine finely granuloscabrate; convex triangular amb and short colpi are diagnostic (pl. 6, fig. 5, 6).

Tricolpites $\mathrm{sp} . \mathrm{F}$-oblate, convex triangular amb; equatorial diameter about $45 \mu \mathrm{m}$; colpi moderately long, exine 1.0-1.5 $\mu \mathrm{m}$ thick, faintly scabro-verrucate, and very finely infrabaculate; large size, tectate exine and moderate colpi are diagnostic; very similar to Tricolpites sp. 175 bis, from which it differs by having shorter colpi, and a thicker wall (pl. 6, fig. 10,11).

Tricolpites sp. $\mathrm{G}$ - subspherical, equatorial diameter $26 \mu \mathrm{m}$; colpi long, exine 1.5-2.0 $\mu \mathrm{m}$ thick; densely foveolate very finely at poles grading to $0.5 \mu \mathrm{m}$ in diameter at equator; long colpi and graded reticulum diagnostic (pl. 6, fig. 9).

Tricolpites sp. $\mathrm{H}$-subspherical to slightly oblate, equatorial diameter 35-45 $\mu \mathrm{m}$; colpi moderately long; exine about $1 \mu \mathrm{m}$ thick; moderate to dense cover of low verrucae 1-2 $\mu \mathrm{m}$ in diameter; strongly and densely infrabaculate (baculae $0.3-0.5 \mu \mathrm{m}$ in diameter); large size and "spotted" appearance diagnostic (pl. 7, fig. 1).

Tricolpites sp. I-oblate, subcircular amb; equatorial diameter 28-35 $\mu \mathrm{m}$; colpi short; end-exine thin; ectexine has very dense pila 1.0 $1.5 \mu \mathrm{m}$ long forming distal fine reticulum, lumina irregular 0.5-1.0 $\mu \mathrm{m}$ in diameter; muri thin, supported by a single row of pila; large size, short colpi, and strong tegillum are diagnostic; $T$. gigantoreticulatus is larger, and has long colpi (pl. 7, fig. 2, 3).

Tricolpites sp. J-subspherical; equatorial diameter $45-48 \mu \mathrm{m}$; colpi long; exine about $2 \mu \mathrm{m}$ thick, no layering visible, covered densely with low verrucae $2-3 \mu \mathrm{m}$ in diameter; long colpi, large verrucae and nontegillate exine are diagnostic and distinguish it from Tricolpites sp. F (pl. 7, fig. 4).

Trifossapollenites ivoirensis Jardine and Magloire, 1965, S.CI 398 (pl. 7, fig. 9).

\section{Monocolpate Pollen}

Liliacidites crassatus Singh, 1971.

Liliacidites dividuus (Pierce, 1961), Brenner, 1963 (pl. 7, fig. 6).

Liliacidites inaequalis Singh, 1971 (pl. 7, fig. 8).

Liliacidites peroreticulatus (Brenner, 1963) Singh, 1971.

Liliacidites reticulatus (Brenner, 1963) Singh, 1971.

Liliacidites textus Norris, 1967 (pl. 7, fig. 7).

Retimonocolpites sp. Herngreen, 1973-differs from $L$. dividuus by having a much finer reticulum, and much shorter pila, so as to appear almost single layered.

\section{Porate Pollen}

Cretacaeiporites muellerii Herngreen, 1973 (pl. 8, fig. 4).

Cretacaeiporites polygonalis (Jardine and Magloire, 1965) Herngreen, 1973 (pl. 8, fig. 3).

Cretacaeiporites scabratus Herngreen, 1973-the criteria suggested by Boltenhagen (1975) to distinguish C. scabratus have not proved workable, so all specimens of this type have been assigned to $C$. scabratus (pl. 8, fig. 1, 2,6).

Triorites sp. A-oblate subcircular to convexly triangular amb; equatorial diameter $16 \mu \mathrm{m}$; exine $1 \mu \mathrm{m}$ thick, very finely reticulate (pl. 8, fig. 5).

\section{Complex Aperturate Pollen}

Hexaporotricolpites coronatus Jardine, 1972 (pl. 8, fig. 9).

Hexaporotricolpites emelianovi Boltenhagen, 1967 (pl. 8, fig. 7, 8). Hexaporotricolpites potoniei Boltenhagen, 1969 (pl. 9, fig. 1).

Syncolporites form B S.CI. 146 Jardine and Magloire, 1965 (pl. 9 , fig. 2, 3).

Syndemicolpites sp. A-oblate; amb rounded isosceles triangular with straight to slightly concave sides; short equatorial diameter about $27 \mu \mathrm{m}$, long diameter about $33 \mu \mathrm{m}$; three radial colpi extend from close to pole to close to equator on both sides of grain; exine 1.5-2 $\mu \mathrm{m}$ thick, thickest at radial extremities, finely scabrate; tyecies Syndemicolpites typicus Van Hoeken-Klinkenberg, 1962, from the Nigerian Maestrichtian is reticulate (pl. 9, fig. 4, 5).

Tricolporopolleites sp. S.CI. 260 Jardine and Magloire, 1965, slightly oblate, $22 \mu \mathrm{m}$ equatorial diameter, distinctly tricolporate; endexine 1-2 $\mu \mathrm{m}$ thick, homogeneous; extexine $0.5-1 \mu \mathrm{m}$ thick, foveoreticulate, very fine at colpal margin and poles, coarse and irregular (lumina about $2 \mu \mathrm{m}$ across) elsewhere; may occur in tetrads.

Tricolporopollenites sp. CI. 100 Jardine and Maglore, 1965.

\section{Incertae Sedis}

Incertae Sedis sp. A-Inaperturate sphere about $30 \mu \mathrm{m}$ in diameter with a sparse and patchy cover of short gemmae about $1 \mu \mathrm{m}$ long. This taxon may be an inaperturate pollen (pl. 9, fig. 8).

Reticulatasporites jardinus Brenner, 1968 (pl. 9, fig. 9).

\section{Dinoflagellates}

All dinoflaggellate references not to be found in the bibliography are available in Lentin and Williams (1973).

Achomosphaera sagena Davey and Williams, 1966a.

Aptea polymorpha Eisenack, 1958.

Apteodinium conjunctum Eisenack and Cookson, 1960.

Ascodinium acrophorum Cookson and Eisenack, 1960; specimens from the Angola Basin differ from Australian Ascodinium specimens by being more elongate, with the wall layers closer together at the cingulum (pl. 10, fig. 1, 2).

Ascolinium cf. A. serratum Cookson and Eisenack, 1960-specimens are not as strongly serrated on the antapex as the holotype of $A$. serratum. Coronifera oceanica Cookson and Eisenack, 1958.

Cribroperidinium edwardsii (Cookson and Eisenack, 1958) Davey, 1969a. Cyclonephelium distinctum Deflandre and Cookson, 1955 (pl. 10, fig. 3). Deflandrea acuminata Cookson and Eisenack, 1958 (pl. 10, fig. 4).

Diconodinium arcticum Manum and Cookson, 1964 -all speciments of Diconodium with sparse granulation are included in this species.

Dinogymnium acuminatum Evitt et al., 1967 (pl 10, fig. 7, 8).

Dinogymium euclaensis Cookson and Eisenack, 1970 (pl. 10, fig. 5, 6). Dinopterygium cladoides Deflandre, 1935.

Dioxya villosa Eisenack and Cookson, 1960 (pl. 11, fig. 1).

Exochosphaeridium phragmites Davey et al. (1966).

Florentinia deanei (Davey and Williams, 1966) Davey and Verdier, 1973. Gonyaulacysta cassidata (Eisenack and Cookson, 1960) Sarjeant, 1966. Gonyaulacysta helicoidea (Eisenack and Cookson, 1960) Sarjeant, 1966. Hexagonifera chlamydata Cookson and Eisenack, 1962.

Hystrichodinium pulchrum Deflandre, 1935.

Hystrichosphaeridium arundum Eisenack and Cookson, 1960 (pl. 11, fig. 2).

Leptodinium sp. A-cysts (65-75 $\mu \mathrm{m}$ long and 60-65 $\mu \mathrm{m}$ broad; sutural crests $4-5 \mu \mathrm{m}$ high, fibrous and highly perforate, lumina up to $3-4 \mu \mathrm{m}$ in diameter, distal extremity of crests bear numerous short spines 1-2 $\mu \mathrm{m}$ long along their length; endophragm finely and evenly granular, or finely reticulate; precingular archeopyle (pl. 11, fig. 3,4).

Leptodinium spp.-simple smooth-walled forms with simple psilate sutural crests (pl. 11, fig. 5).

Litosphaeridium conispinum Davey and Verdier, 1973 (pl. 11, fig. 6).

Litosphaeridium siphoniphorum (Cookson and Eisenack, 1958) Davey and Williams, 1966 (pl. 11, fig. 7).

Odontochitina operculata (O. Wetzel, 1933) Deflandre and Cookson, 1955.

Oligosphaeridium complex (White, 1842) Davey and Williams, 1966 (pl. 12, fig. 1). 
Palaeohystrichophora infusiorioides Deflandre, 1935 (pl. 12, fig. 2). Psaligonyaulax deflandrei Sarjeant, 1966.

Spiniferites ramosus (Ehrenberg, 1838) Loeblich and Loeblich, 1966. Spiniferites sp.-cysts about $70 \times 62 \mu \mathrm{m}$, exclusive of ornament; low sutural crests about $1 \mu \mathrm{m}$ high bear numerous hollow 5-6 $\mu \mathrm{m}$ long bifurcation spines; after $3-4 \mu \mathrm{m}$, a second bifurcation occurs, the final elements being 1-2 $\mu \mathrm{m}$ long; spines gonal and scattered along suture; $15-20$ spines outline each reflected plate area; both wall layers smooth; precingular archeopyle (pl. 12, fig. 3).

Subtilisphaera cf. S. perlucida (Alberti, 1959) Jain and Millepied, 1973-specimens differ from $S$. perlucida by having a fine even cover of granules or short spines to $0.5 \mu \mathrm{m}$ long; suggestion on some specimens of a archeopyle involving loss of plate $2 \mathrm{a}$ and detachment of plate 3 everywhere except along the cingulum, present on some specimens (pl. 12, fig. 4, 5).

Tanyosphaeridium variecalamum Davey and Williams, 1966b.

Trichodinium intermedium Eisenack and Cookson, 1960.

\section{Acritarchs}

Crassosphaera concinna Cookson and Manum, 1960 (pl. 12, fig. 10), Cymatiosphaera spp.-various simple species.

Cymatiosphaera sp. A-small spherical form about $16 \mu \mathrm{m}$ in diameter exclusive of ledges; ledges $2-3 \mu \mathrm{m}$ high, smooth, outlining 15-20 pentagonal or hexagonal fields 6-7 $\mu \mathrm{m}$ in diameter; at three point junctions, a central hollow tube $0.5 \mu \mathrm{m}$ exists, giving a characteristic pattern (pl. 12, fig. 9).

Micrhystridium spp.-various simple forms (pl. 12, fig. 7, 8).

Pterospermella australensis (Deflandre and Cookson, 1955) Cookson and Eisenack, 1974.

Pterospermella spp. various simple forms (pl. 12, fig. 6).

Veryhachium spp. various simple forms.

\section{CONCLUSIONS}

Site 364, in the south eastern Angola Basin, bottomed in early Albian sediments representing a cyclicly restricted basin with minor marine influence. The basin was bounded to the east and north by Africa, to the west by South America, and to the south by the Walvis Ridge. Marine influence, apparently over the Walvis Ridge was cyclic but very slight in the early Albian. The middle and late Albian were times of more open marine circulation, but the basin again became cyclicly restricted in the late Albian and probably the Cenomanian. Deposition was probably continuous through the Cenomanian and Turonian, but most of this interval is now absent from Site 364. Possibly, Cenomanian and Turonian sediments were eroded during the period of changing currents accompanying the Turonian separation to the north of Africa and South America. By the late Turonian or Coniacian, sedimentation resumed at Site 364 in the still restricted basin, with contemporaneous erosion of Cenomanian and Turonian rocks in the area, resulting in significant reworking into Site 364 . The lithological expression of this hiatus has not yet been recognized in the consecutive Cores 25, 26, and 27. Within the Senonian, Site 364 became progressively more open marine as part of the deep sea basin of the present South Atlantic Ocean.

\section{ACKNOWLEDGMENTS}

The author wishes to thank Dr. H.M. Bolli of the Swiss Federal Institute of Technology, Dr. W. Siesser of the University of Cape Town, and the Lamont-Doherty repository for supplying the samples.

Facilities and permission to publish were provided by the Under Secretary, New South Wales Department of Mines. Dr. S. Jardine of the ELF-R.E. Boussens Research Centre, Dr. W. Herngreen of the Netherlands Geological Survey, Mr.
A. Partridge of ESSO Australia, and Dr. B. McGowran of Adelaide University have contributed by discussion and review of the manuscript.

The present contribution is part of the research being carried out by the author for the Ph.D. degree from the University of Adelaide.

\section{REFERENCES}

Archangelsky, S. and Gamerro, J.C., 1967. Spore and pollen types of the Lower Cretaceous in Patagonia (Argentina): Rev. Palaeobot. Palynol., v. 1, p. 211-217.

Balme, B.E., 1957. Spores and pollen grains from the Mesozoic of Western Australia: C.S.I.R.O. Aust. Coal Res. Sect. T.C. 25, p. 1-48.

Bolkhovitina, N.A., 1961. Fossil and recent spores in the Schizaeaceae. Tr. Inst. Geol., Akad. Nauk S.S.S.R. 40, p. 1-176. (in Russian).

Bolli, H.M. et al., 1975. Basins and margins of the eastern South Atlantic: Geotimes, v. 20(6), p. 22-24.

Boltenhagen, E., 1965. Introduction a la palynologie stratigraphique du bassin sedimentaire de l'Afrique equatoriale: Mém. Bur. Rech. Géol. Minières, v. 32, p. $305-327$.

1967. Spores et pollen du Crétacé superieur du Gabon: Pollen et Spores, v. 9, p. 335-355.

1969. Hexaporotricolpites potoniei, espèce nouvelle d'um pollen hexaporotricolpé du Crétacé superieur du Gabon. Grana Palynol., v. 9, p. 169-173.

, 1973. Quelques espèces du genre Classopolis (Pflug)

Reyre du Cretace Superieur du Gabon: Rev. Micropaléontol., v. 16, p. 205-213.

1975. Pollen peripore du Crétacé superieur du Gabon: Rev. Micropaleontol., v. 17, p. 164-170.

Brenner,G.J., 1963. The spores and pollen of the Potomac Group of Maryland: Dept. Mines, Geology, and Water Resources, State of Maryland Bull. 27, p. 1-215.

in press. Middle Cretaceous Floral Provinces and Early Migrations of Angiosperms: Palisades, New York (Columbia University Press).

Cookson, I.C., 1947. Plant microfossils from the lignites of Kerguelen Archipelago: B.A.N.Z. Antarctic Res. Exp. 1929-31, Rept. A2, p. 127-142.

1953. Differences in microspore composition of some samples from a bore at Comaum, South Australia: Aust. J. Bot., v. 1, p. 462-473.

Cookson, I.C. and Dettmann, M.E., 1958. Cretaceous "megaspores" and a closely associated microspore from the Australian region: Micropaleontology, v. 4, p. 39-49.

Cookson, I.C. and Eisenack, A., 1974. Microplankton aus Australischen Mesozoischen und Tertiären Sedimenten: Palaeontographica, v. 148 B, p. 44-93.

Cookson, I.C. and Manum, S., 1960. On Crassosphaera, a New Genus of Microfossils from Mesozoic and Tertiary deposits: Nytt Mag. Bot., v. 8, p. 5-8.

Davey, R.J. and Verdier, J.P., 1973. An investigation of microplankton assemblages from latest Albian (Vraconian) sediments: Rev. Espan. Micropal., v. 5, p. 173-212.

Dettmann, M.E., 1963. Upper Mesozoic Microfloras from South Eastern Australia: Proc. Roy. Soc. Victoria, v. 77, p. 1-148.

1973. Angiospermous Pollen from Albian to Turonian Sediments of Eastern Australia: Spec. Publ. Geol. Soc. Australia, v. 4, p. 3-34.

Groot, J.J. and Penny, J.S., 1960. Plant microfossils of nonmarine Cretaceous sediments of Maryland and Delaware: Micropaleontology, v. 6, p. 225-236. 
Groot, J.J., Penny, J.S., and Groot, C.R., 1961. Plant microfossils and age of the Raritan, Tuscaloosa and Magothy Formation of the eastern United States: Palaeontographica, v. 108B, p. 121-140.

Herngreen, G.F.W., 1973. Palynology of AlbianCenomanian strata of borehole 1-QS-1-MA, State of Maranhao, Brazil: Pollen et Spores, v. 15, p. 515-555. , 1975. Palynology of Middle and Upper Cretaceous strata in Brazil: Meded. Rijks Geol. Dienst., N.S., v. 26, p. 39-91.

Hoeken-Klinkenberg, P.M.J. Van, 1964. A palynological investigation of some Upper Cretaceous sediments in Nigeria: Pollen et Spores, v. 6, p. 209-231.

Jain, K.P. and Millepied, P., 1973. Cretaceous microplankton from Senegal Basin, N.W. Africa I. Some new genera, species and combinations of dinoflagellates: The Palaeobotanist, v. 20, p. 22-32.

Jardine, S., 1967. Spores à expansions en forme d'élaters du Crétacé moyen d'Afrique occidentale: Rev. Palaeobot. Palynol., v. 1, p. 235-258.

Jardine, S., Doerenkamp, A., and Legoux, O., 1972. Le genre Hexaporotricolpites Boltenhagen 1967 morphologie, systématique, stratigraphie et extension geographique: Quart. Coll. Afr. Micropal., p. 175-190.

Jardine, S., Kieser, G. and Reyre, Y., 1974. L'Individualisation progressive du continent Africain vue à travers les données palynologiques de l'ère secondaire: Sci. Géol. Bull., v. 27, p. 69-85.

Jardine, S. and Magloire, L., 1965. Palynologie et stratigraphie du Crétacé des bassins du Sénégal et de Côte d'Ivoire: Mém. Bur. Rech. Géol. Minières, v. 32, p. 187245.

Lentin, J.K. and Williams, G.L., 1973. Fossil Dinoflagellates: Index to Genera and species: Geol. Surv. Canada, Paper 73-42.
Muller, H., 1966. Palynological investigations of Cretaceous sediments in northeastern Brazil: In van Hinte, J.E. (Ed.), Proc. Second West Afr. Micropal. Coll. Ibadan, Proc. 1965. Leiden (Brill), p. 123-136.

Muller, J., 1968. Palynology of the Pedawan and Plateau Sandstone Formation (Cretaceous-Eocene) in Sarawak, Malaysia: Micropaleontology, v. 14, p. 1-37.

Norris, G., 1967. Spores and pollen from the lower Colorado Group (Albian-?Cenomanian) of central Alberta: Palaeontographica, v. 120B, p. 72-115.

Pierce, R.L., 1961. Lower Upper Cretaceous plant microfossils from Minnesota: Minnesota Geol. Surv., Bull., v. 42 , p. $1-86$.

Pocock, S.A.J., 1964. Pollen and spores of the Chlamydospermidae and Schizaeaceae from upper Mannville strata of the Saskatoon area of Saskatchewan: Grana Palynologica, v. 5, p. 129-209.

Reyre, Y., Kieser, G., and Pujol, C., 1970. Interet stratigraphique de quelques éspèces du genus Classopollis (Pflug) Reyre: Rev. Micropaléont., v. 13, p. 146-154.

Rouse, G.E., 1959. Plant microfossils from Kootenay coal measures strata of British Columbia: Micropaleontology, v. 5 , p. 303-324.

Singh, C., 1971. Lower Cretaceous Microfloras of the Peace River Area, Northwestern Alberta: Res. Council Alberta Bull., v. 28, p. 1-542.

Stanley, E.A., 1965. Upper Cretaceous and Paleocene plant microfossils and Paleocene dinoflagellates and hystrichosphaerids from northwestern South Dakota. Am. Paleontol. Bull., v. 49, p. 179-384.

Stover, L.E., 1964. Cretaceous ephedroid pollen from West Africa: Micropaleontology, v. 10, p. 145-156.

Verdier, J.P., 1975. Les Cystes de dinoflagelles de la section de Wissant et leur distribution stratigraphique au Crétacé Moyen: Rev. Micropaléontol., v. 17, p. 191-197. 
APPENDIX

Key to Illustrated Specimens

\begin{tabular}{|c|c|c|c|c|}
\hline Plate & Figure & Palyn. No. & M.M.M.C. No. & Co-ordinates \\
\hline 1 & 1 & $2538 / \mathrm{b}$ & 2049 & $105 / 0923$ \\
\hline 1 & 2 & $2538 / \mathrm{a}$ & 2048 & $188 / 0950$ \\
\hline 1 & 3 & $2511 / \mathrm{a}$ & 2039 & $062 / 0970$ \\
\hline 1 & 4 & $2538 / \mathrm{a}$ & 2048 & $040 / 0948$ \\
\hline 1 & 5 & 2511/a & 2039 & $080 / 0928$ \\
\hline 1 & 6 & $2538 / \mathrm{a}$ & 2048 & $078 / 1080$ \\
\hline 1 & 7 & $2511 / \mathrm{a}$ & 2039 & $180 / 1065$ \\
\hline 1 & 8 & $2538 / \mathrm{a}$ & 2048 & $042 / 0885$ \\
\hline 1 & 9 & $2538 / \mathrm{a}$ & 2048 & $023 / 0918$ \\
\hline 1 & 10 & $2535 / \mathrm{a}$ & 2047 & $050 / 1125$ \\
\hline 1 & 11 & $2511 / \mathrm{a}$ & 2039 & $205 / 0974$ \\
\hline 1 & 12 & $2532 / \mathrm{c}$ & 2045 & $063 / 1051$ \\
\hline 1 & 13 & $2509 / \mathrm{a}$ & 2036 & $022 / 1060$ \\
\hline 2 & 1 & $2511 / \mathrm{b}$ & 2040 & $030 / 1080$ \\
\hline 2 & 2 & $2511 / \mathrm{a}$ & 2039 & $152 / 0993$ \\
\hline 2 & 3 & $2532 / \mathrm{a}$ & 2043 & $123 / 0936$ \\
\hline 2 & 4 & $2532 / \mathrm{a}$ & 2043 & $052 / 1068$ \\
\hline 2 & 5 & $2511 / a$ & 2039 & $058 / 1128$ \\
\hline 2 & 6 & $2509 / \mathrm{a}$ & 2036 & $045 / 0952$ \\
\hline 2 & 7 & $2511 / \mathrm{a}$ & 2039 & $200 / 0883$ \\
\hline 2 & 8 & $2538 / \mathrm{a}$ & 2048 & $060 / 0880$ \\
\hline 2 & 9 & $2510 / \mathrm{a}$ & 2037 & $152 / 0820$ \\
\hline 3 & 1 & $2534 / \mathrm{a}$ & 2046 & $205 / 0910$ \\
\hline 3 & 2 & $2535 / \mathrm{a}$ & 2047 & $105 / 0970$ \\
\hline 3 & 3 & $2511 / \mathrm{a}$ & 2039 & $082 / 1090$ \\
\hline 3 & 4 & $2532 / \mathrm{a}$ & 2043 & $123 / 0851$ \\
\hline 3 & 5 & $2539 / \mathrm{a}$ & 2050 & $105 / 1008$ \\
\hline 3 & 6 & $2539 / \mathrm{a}$ & 2050 & $087 / 1014$ \\
\hline 3 & 7 & $2511 / \mathrm{a}$ & 2039 & $206 / 0938$ \\
\hline 3 & 8 & $2539 / \mathrm{a}$ & 2050 & $038 / 1053$ \\
\hline 4 & 1 & $2511 / \mathrm{a}$ & 2039 & $092 / 0910$ \\
\hline 4 & 2 & $2539 / \mathrm{a}$ & 2050 & $202 / 1120$ \\
\hline 4 & 3 & $2511 / \mathrm{a}$ & 2039 & $104 / 1050$ \\
\hline 4 & 4 & $2511 / \mathrm{a}$ & 2039 & $158 / 0962$ \\
\hline 4 & 5 & $2538 / \mathrm{b}$ & 2049 & $230 / 1122$ \\
\hline 4 & 6 & $2532 / \mathrm{c}$ & 2045 & $063 / 1145$ \\
\hline 4 & 7 & $2538 / \mathrm{a}$ & 2048 & $153 / 0862$ \\
\hline 4 & 8 & $2539 / \mathrm{a}$ & 2050 & $160 / 1175$ \\
\hline 4 & 9 & $2532 / \mathrm{a}$ & 2043 & $092 / 1038$ \\
\hline 4 & 10 & $2530 / \mathrm{a}$ & 2042 & $170 / 1230$ \\
\hline 4 & 11 & $2534 / \mathrm{a}$ & 2046 & $025 / 0998$ \\
\hline 4 & 12 & $2511 / \mathrm{a}$ & 2039 & $142 / 1152$ \\
\hline 4 & 13 & $2534 / \mathrm{a}$ & 2046 & $025 / 0998$ \\
\hline 4 & 14 & $2532 / \mathrm{c}$ & 2045 & $040 / 0970$ \\
\hline 4 & 15 & $2532 / \mathrm{c}$ & 2045 & $100 / 0855$ \\
\hline 5 & 1 & $2511 / \mathrm{a}$ & 2039 & $202 / 1052$ \\
\hline 5 & 2 & $2511 / \mathrm{a}$ & 2039 & $113 / 0885$ \\
\hline 5 & 3 & $2532 / \mathrm{c}$ & 2045 & $188 / 0904$ \\
\hline 5 & 4 & $2538 / \mathrm{b}$ & 2049 & $153 / 0903$ \\
\hline 5 & 5 & $2532 / \mathrm{a}$ & 2043 & $183 / 0967$ \\
\hline 5 & 6 & $2511 / \mathrm{b}$ & 2040 & $155 / 1188$ \\
\hline 5 & 7 & $2538 / \mathrm{a}$ & 2048 & $062 / 0835$ \\
\hline 5 & 8 & $2538 / \mathrm{a}$ & 2048 & $180 / 0890$ \\
\hline 5 & 9 & $2509 / \mathrm{a}$ & 2036 & $157 / 0890$ \\
\hline 5 & 10 & $2509 / \mathrm{a}$ & 2036 & $108 / 0982$ \\
\hline 5 & 11 & $2535 / \mathrm{a}$ & 2047 & $197 / 1222$ \\
\hline 5 & 12 & $2509 / \mathrm{a}$ & 2036 & $176 / 1100$ \\
\hline 5 & 13 & $2538 / a$ & 2048 & $122 / 1055$ \\
\hline 5 & 14 & $2538 / \mathrm{a}$ & 2048 & $020 / 0762$ \\
\hline 6 & 1 & $2535 / a$ & 2047 & $184 / 1060$ \\
\hline 6 & 2 & $2509 / \mathrm{a}$ & 2036 & $050 / 1180$ \\
\hline
\end{tabular}

\begin{tabular}{|c|c|c|}
\hline Plate & Figure & $\mathrm{Pal}$ \\
\hline
\end{tabular}

\begin{tabular}{|c|c|c|c|c|}
\hline 6 & 3 & $2511 / \mathrm{a}$ & 2039 & $099 / 0930$ \\
\hline 6 & 4 & $2511 / \mathrm{a}$ & 2039 & $060 / 1146$ \\
\hline 6 & 5 & 2538/a & 2048 & $200 / 1022$ \\
\hline 6 & 6 & $2538 / \mathrm{b}$ & 2049 & $138 / 1008$ \\
\hline 6 & 7 & $2511 / \mathrm{a}$ & 2039 & $078 / 0854$ \\
\hline 6 & 8 & $2511 / \mathrm{b}$ & 2040 & $113 / 1120$ \\
\hline 6 & 9 & $2538 / \mathrm{a}$ & 2048 & $163 / 0970$ \\
\hline 6 & 10 & $2539 / \mathrm{a}$ & 2050 & $177 / 1073$ \\
\hline 6 & 11 & $2510 / \mathrm{b}$ & 2038 & $148 / 0902$ \\
\hline 7 & 1 & $2539 / \mathrm{a}$ & 2050 & $032 / 1162$ \\
\hline 7 & 2 & $2539 / \mathrm{a}$ & 2050 & $218 / 1048$ \\
\hline 7 & 3 & $2539 / \mathrm{a}$ & 2050 & $090 / 1162$ \\
\hline 7 & 4 & $2539 / \mathrm{a}$ & 2050 & $220 / 0892$ \\
\hline 7 & 5 & $2511 / \mathrm{a}$ & 2039 & $138 / 1128$ \\
\hline 7 & 6 & 2509/a & 2036 & $202 / 1138$ \\
\hline 7 & 7 & $2511 / \mathrm{a}$ & 2039 & $156 / 0980$ \\
\hline 7 & 8 & $2509 / \mathrm{a}$ & 2036 & $030 / 1208$ \\
\hline 7 & 9 & $2535 / \mathrm{a}$ & 2047 & $070 / 1146$ \\
\hline 8 & 1 & $2538 / \mathrm{b}$ & 2049 & $051 / 0990$ \\
\hline 8 & 2 & $2539 / \mathrm{a}$ & 2050 & $032 / 0946$ \\
\hline 8 & 3 & $2539 / \mathrm{a}$ & 2050 & $215 / 0881$ \\
\hline 8 & 4 & $2538 / \mathrm{b}$ & 2049 & $192 / 1018$ \\
\hline 8 & 5 & $2538 / \mathrm{a}$ & 2048 & $070 / 0825$ \\
\hline 8 & 6 & $2529 / \mathrm{a}$ & 2050 & $227 / 0982$ \\
\hline 8 & 7 & $2538 / \mathrm{a}$ & 2048 & $158 / 0930$ \\
\hline 8 & 8 & $2511 / \mathrm{a}$ & 2039 & $120 / 0910$ \\
\hline 8 & 9 & $2538 / \mathrm{b}$ & 2049 & $035 / 1016$ \\
\hline 9 & 1 & $2538 / \mathrm{b}$ & 2049 & $102 / 0978$ \\
\hline 9 & 2 & $2538 / \mathrm{b}$ & 2049 & $218 / 1085$ \\
\hline 9 & 3 & $2538 / \mathrm{a}$ & 2048 & $195 / 0922$ \\
\hline 9 & 4 & $2530 / \mathrm{a}$ & 2042 & $022 / 1030$ \\
\hline 9 & 5 & $2539 / \mathrm{a}$ & 2050 & $130 / 1156$ \\
\hline 9 & 6 & $2539 / \mathrm{a}$ & 2050 & $130 / 1040$ \\
\hline 9 & 7 & $2532 / \mathrm{c}$ & 2045 & $044 / 1188$ \\
\hline 9 & 8 & $2511 / \mathrm{a}$ & 2039 & $170 / 1152$ \\
\hline 9 & 9 & $2532 / \mathrm{b}$ & 2044 & $152 / 0832$ \\
\hline 10 & 1 & $2510 / \mathrm{a}$ & 2037 & $152 / 0867$ \\
\hline 10 & 2 & $2510 / \mathrm{a}$ & 2037 & $026 / 1001$ \\
\hline 10 & 3 & $2538 / \mathrm{b}$ & 2049 & $078 / 1194$ \\
\hline 10 & 4 & $2539 / \mathrm{a}$ & 2050 & $047 / 1070$ \\
\hline 10 & 5 & $2530 / \mathrm{a}$ & 2042 & $032 / 1060$ \\
\hline 10 & 6 & 2539/a & 2050 & $056 / 0874$ \\
\hline 10 & 7 & $2539 / \mathrm{a}$ & 2050 & $013 / 0970$ \\
\hline 11 & 1 & $2509 / \mathrm{a}$ & 2036 & $023 / 1170$ \\
\hline 11 & 2 & $2535 / \mathrm{a}$ & 2047 & $232 / 1223$ \\
\hline 11 & 3 & $2532 / \mathrm{a}$ & 2043 & $043 / 1040$ \\
\hline 11 & 4 & $2532 / \mathrm{c}$ & 2045 & $032 / 1040$ \\
\hline 11 & 5 & $2532 / \mathrm{a}$ & 2043 & $096 / 0970$ \\
\hline 11 & 6 & $2511 / \mathrm{b}$ & 2040 & $030 / 1021$ \\
\hline 11 & 7 & $2538 / \mathrm{b}$ & 2049 & $128 / 1168$ \\
\hline 12 & 1 & $2532 / \mathrm{c}$ & 2045 & $184 / 1083$ \\
\hline 12 & 2 & $2538 / \mathrm{b}$ & 2049 & $184 / 1104$ \\
\hline 12 & 3 & $2539 / \mathrm{a}$ & 2050 & $067 / 1084$ \\
\hline 12 & 4 & $2512 / \mathrm{a}$ & 2041 & $135 / 1168$ \\
\hline 12 & 5 & $2512 / \mathrm{a}$ & 2041 & $042 / 1180$ \\
\hline 12 & 6 & $2510 / \mathrm{a}$ & 2037 & $190 / 1040$ \\
\hline 12 & 7 & $2535 / \mathrm{a}$ & 2047 & $208 / 1213$ \\
\hline 12 & 8 & $2538 / \mathrm{a}$ & 2048 & $028 / 0920$ \\
\hline 12 & 9 & $2510 / \mathrm{a}$ & 2037 & $196 / 1040$ \\
\hline 12 & 10 & $2510 / \mathrm{a}$ & 2037 & $012 / 0850$ \\
\hline
\end{tabular}





\section{PLATE 1}

All $\times 1000$ unless otherwise indicated

Figure 1a, b Cicatricosisporites pseudotripartitus, $\times 400$. Sample $24-2,138-140 \mathrm{~cm}$.

Figure 2 Circulina? sp. S.CI. 303. Sample 24-2, 138-140 cm.

Figure 3 Circulina? sp. S.CI. 303. Sample 29-2, 43-44 cm.

Figure 4 Classopollis maljawkineae. Sample 24-2, 138-140 $\mathrm{cm}$.

Figure 5 Classopollis perplexus. Sample 29-2, 43-44 cm.

Figure 6 Classopollis aff. C. senegalensis. Sample 24-2, 138$140 \mathrm{~cm}$.

Figure 7 Classopollis aff. C. senegalensis. Sample 29-2, 43$44 \mathrm{~cm}$.

Figure $8 \quad$ Classopollis klausi. Sample 24-2, 138-140 cm.

Figure 9a, b Classopollis jardinei. Sample 24-2, 138-140 cm.

Figure 10 Cycadopites ovatus. Samples 40-4, 35-37 cm.

Figure 11 Tsugaepollenites trilobatus. Sample 29-2, 43-44 cm.

Figure 12 Tsugaepollenites dampieri, $\times 400$. Sample 44-4, 36$38 \mathrm{~cm}$.

Figure 13 Monosulcites sp. S.CI. 287. Sample 40-5, $51-53 \mathrm{~cm}$. 


\section{PLATE 1}
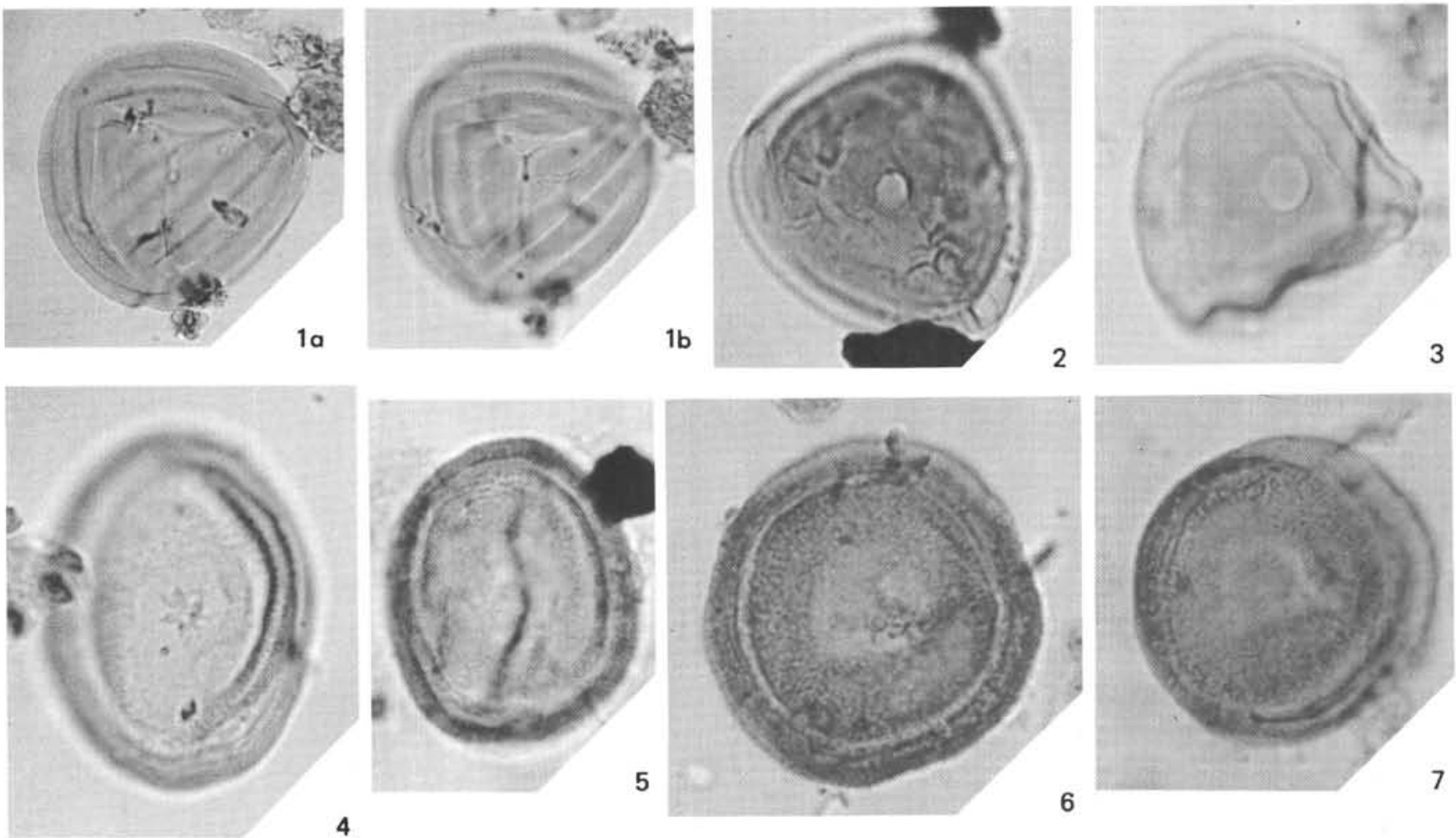

4
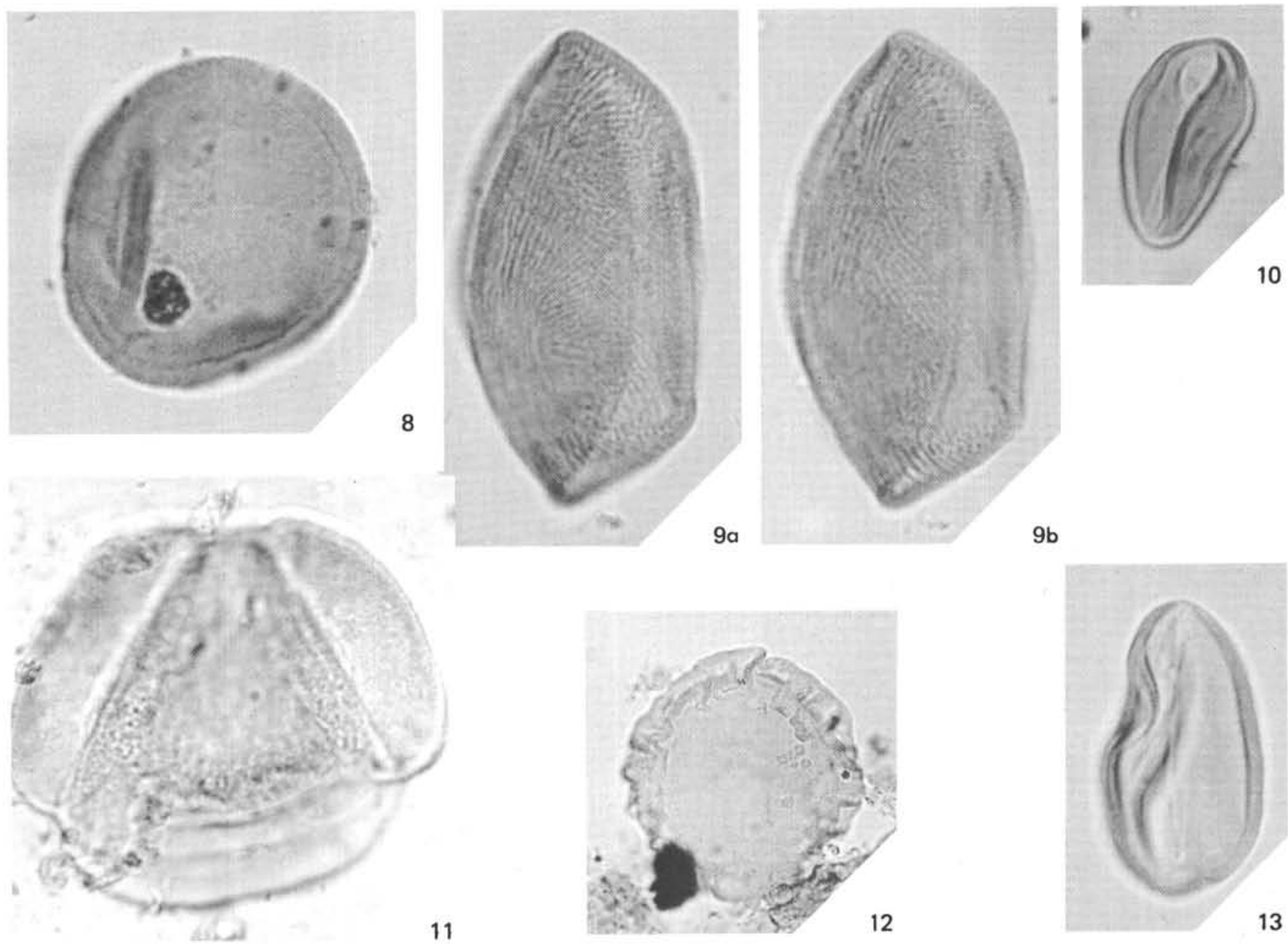


\section{PLATE 2}

All $\times 1000$ unless otherwise indicated

Figure 1a, b Elateroplicites africaensis. Sample 29-2, 43-44 cm.

Figure 2a, b Elateroplicites africaensis. Sample 29-2, 43-44 cm.

Figure 3a, b Ephedripites barghoornii/staplinii. Sample 44-4, $36-38 \mathrm{~cm}$.

Figure 4a, b Ephedripites jansonii. Sample 44-4, 36-38 cm.

Figure 5 Ephedripites sp. 1. Sample 29-2, $43-44 \mathrm{~cm}$.

Figure 6 Ephedripites sp. 5. Sample 40-5, $51-53 \mathrm{~cm}$.

Figure 7 Ephedripites sp. 2. Sample 29-2, $43-44 \mathrm{~cm}$.

Figure 8a, b Ephedripites sp. 1. Sample 24-2, 138-140 cm.

Figure 9a-c Ephedripites sp. 2. Sample 25-3, 67-69 cm. 
PLATE 2
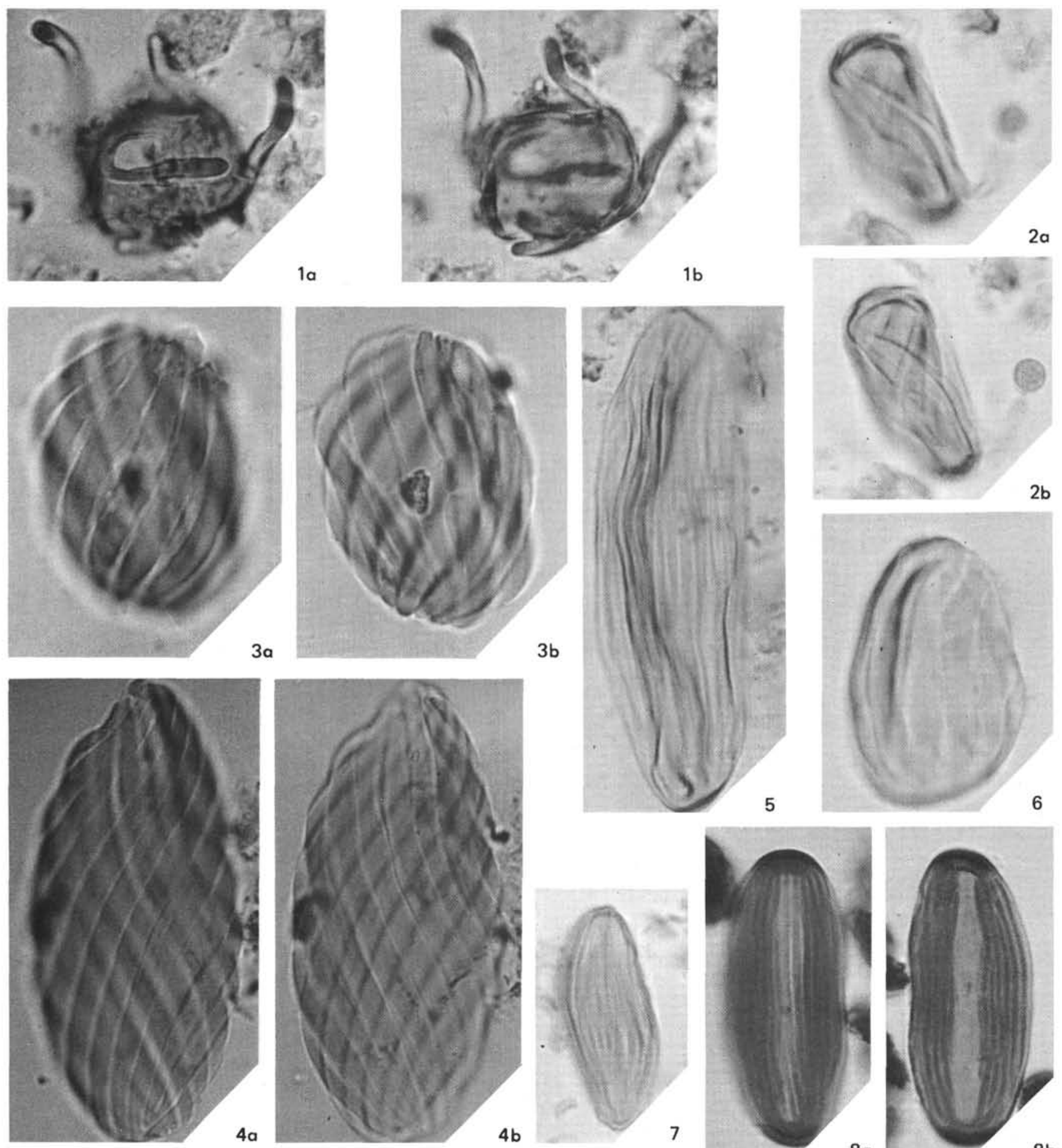

$3 b$
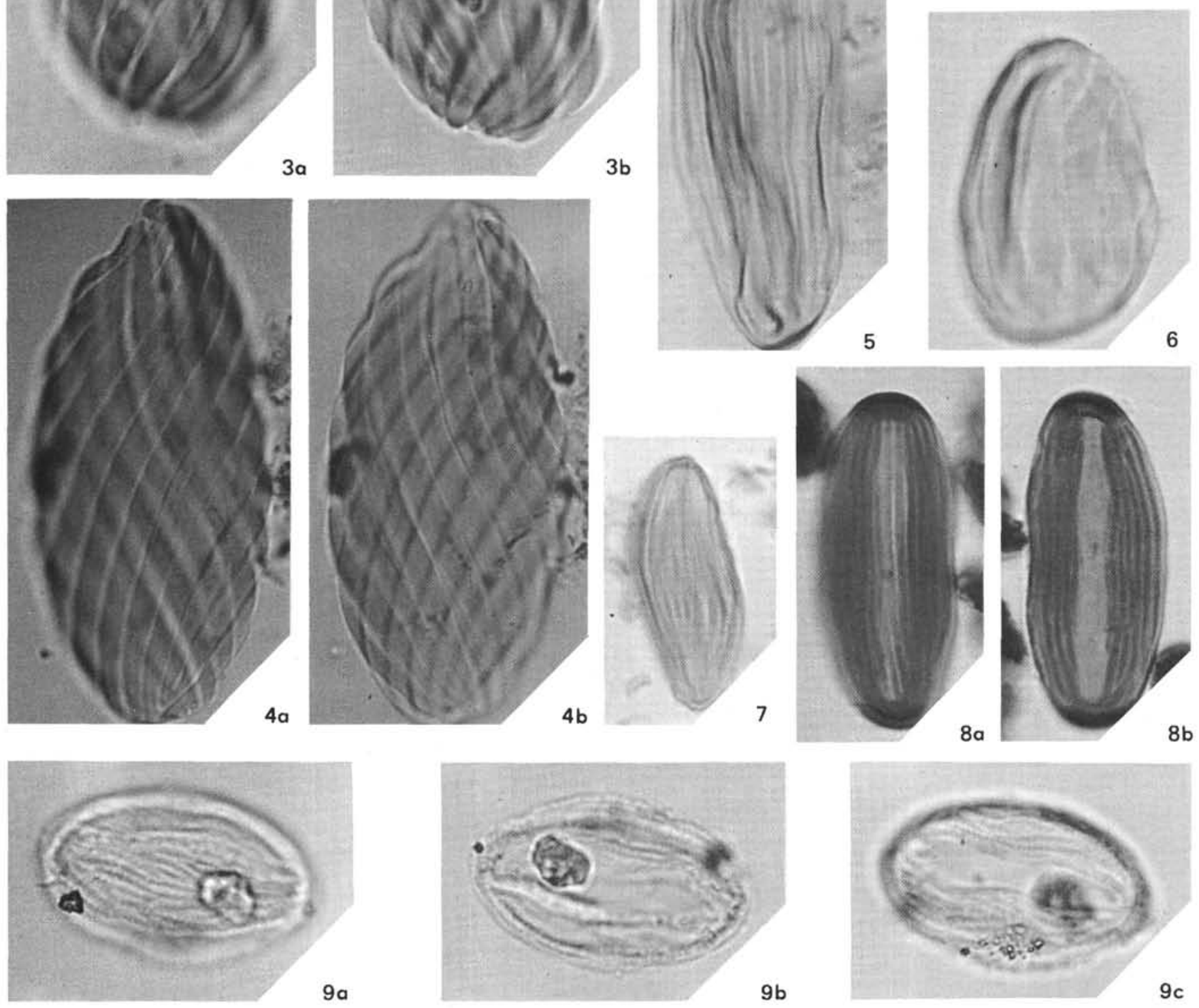
PLATE 3

All $\times 1000$ unless otherwise indicated

Figure 1a, b Gnetaceaepollenites diversus. Sample 39-1, 129-130 $\mathrm{cm}$.

Figure 2a, b Ephedripites sp. 3. Sample 40-4, 35-37 cm.

Figure 3a-c Steevesipollenites binodosus. Sample 29-2, 43-44 $\mathrm{cm}$.

Figure $4 \quad$ Steevesipollenites multilineatus. Sample 44-4, 36-38 $\mathrm{cm}$.

Figure 5a, b Ephedripites sp. C. Sample 23-4, 123-125 cm.

Figure 6a, b Ephedripites sp. B. Sample 23-4, 123-125 cm.

Figure 7a-c Ephedripites sp. 3. Sample 29-2, 43-44 cm.

Figure 8a, b Ephedripites sp B. Sample 23-4, 123-125 cm. 
PLATE 3
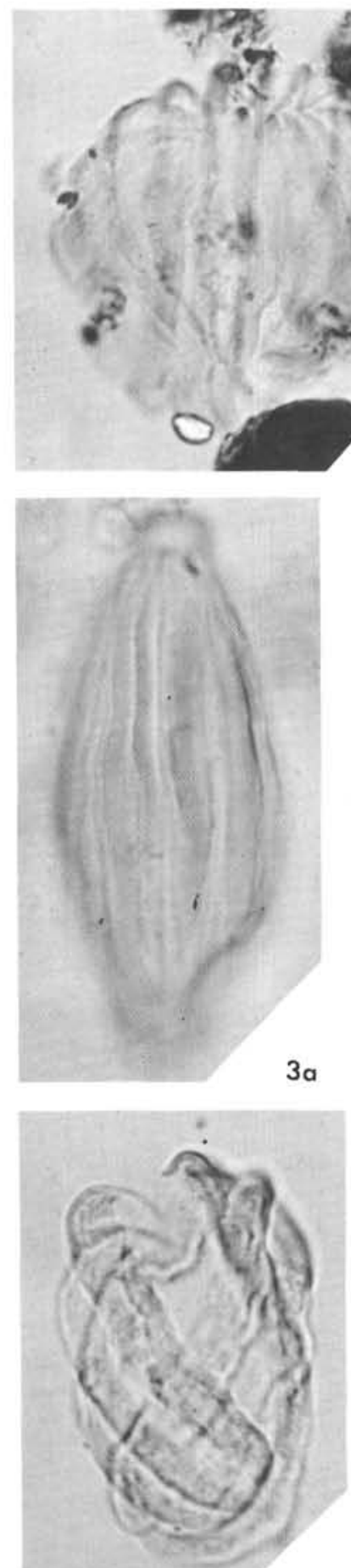

$5 a$

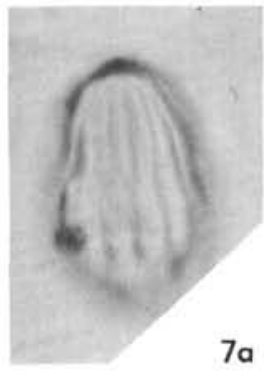

$7 a$
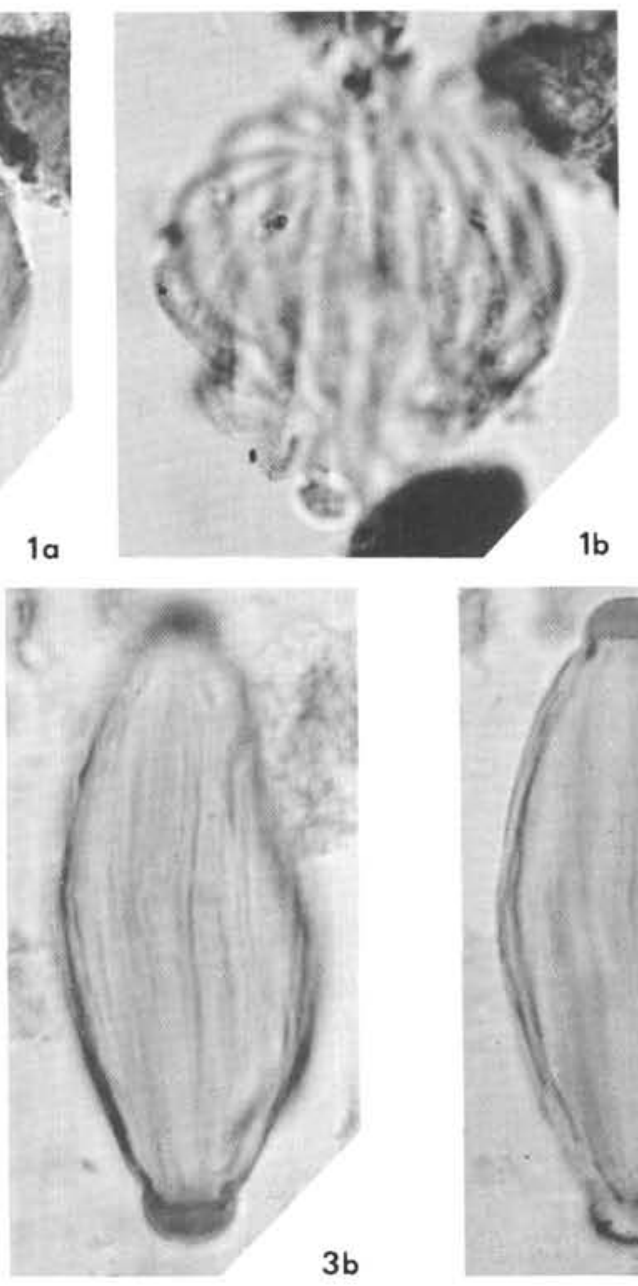

$3 b$

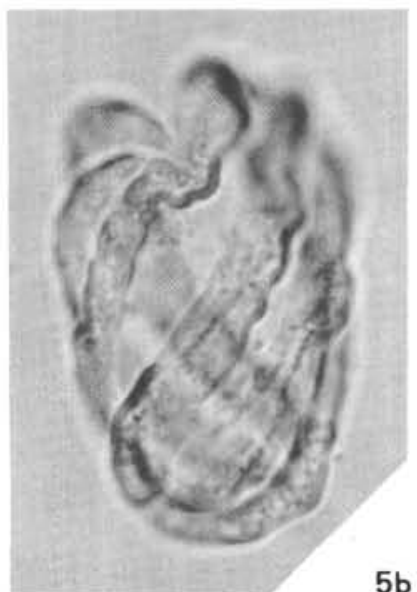

$5 b$

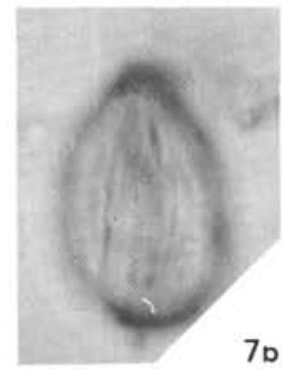

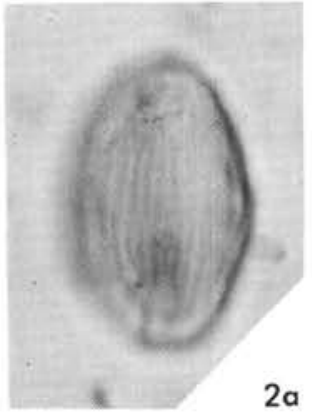

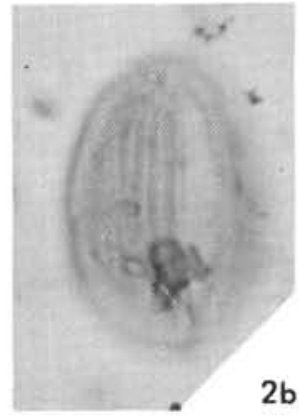

2b

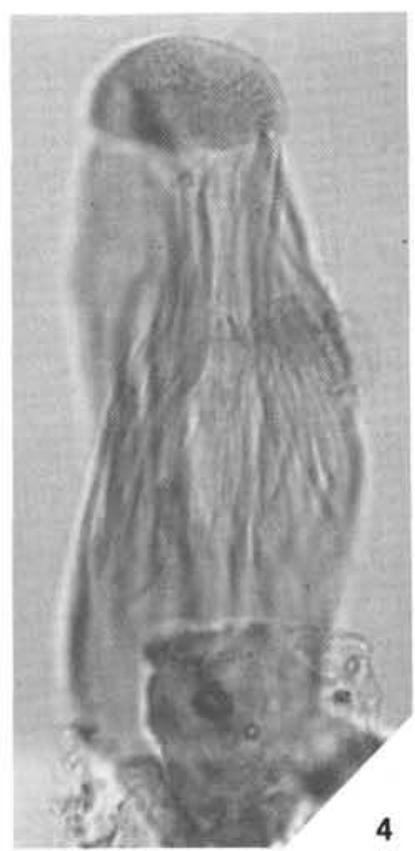

3c
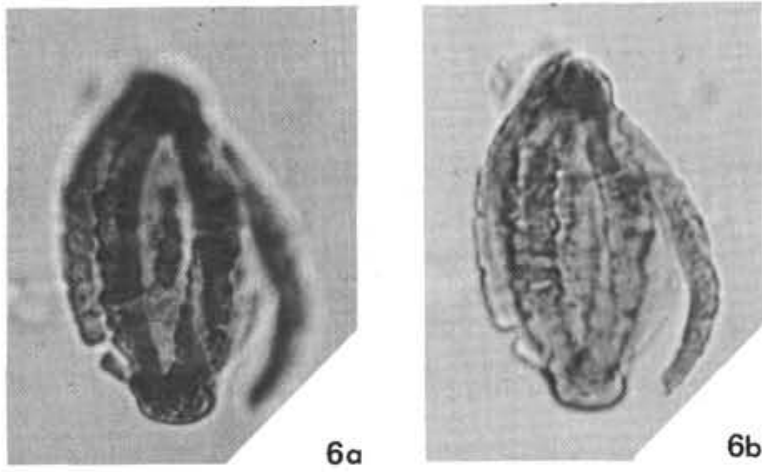

$6 b$
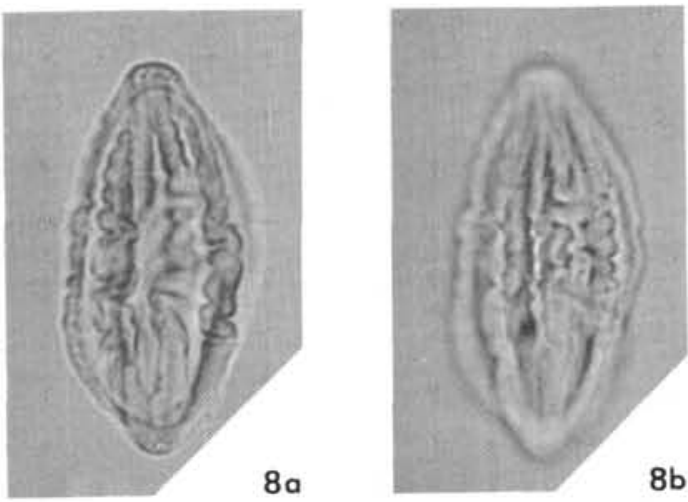


\section{PLATE 4}

All $\times 1000$ unless otherwise indicated

Figure 1a, b Cupuliferoidaepollenites minutus. Sample 29-2, 43$44 \mathrm{~cm}$.

Figure 2a, b Fraxinoipollenites venustus. Sample 23-4, 123-125 $\mathrm{cm}$.

Figure 3a, b Psilatricolpites parvulus. Sample 29-2, 43-44 cm.

Figure 4a, b Psilatricolpites parvulus. Sample 29-2, 43-44 cm.

Figure 5a, b Psilatricolpites parvulus. Sample 24-2, 138-140 cm.

Figure 6a-c Retitricolpites sp. A. Sample 44-4, 36-38 cm.

Figure 7a, b Retitricolpites operculatus. Sample 24-2, 138-140 cm.

Figure 8a, b Retitricolpites virgeus. Sample 23-4, 123-125 cm.

Figure 9a-c Retitricolpites virgeus. Sample 44-4, 36-38 cm.

Figure $10 \quad$ Retitricolpites virgeus. Sample 23-3, 128-130 cm.

Figure 11 Retitricolpites vulgaris. Sample 39-1, 129-130 cm.

Figure 12a, b Retitricolpites vulgaris. Sample 29-2, 43-44 cm.

Figure 13a, b. Retitricolpites vulgaris. Sample 39-1, 129-130 cm.

Figure 14a-c Striatopollis sp. A. Sample 44-4, 36-38 cm.

Figure 15a, b Striatopollis sp. A. Sample 44-4, 36-38 cm. 
PLATE 4
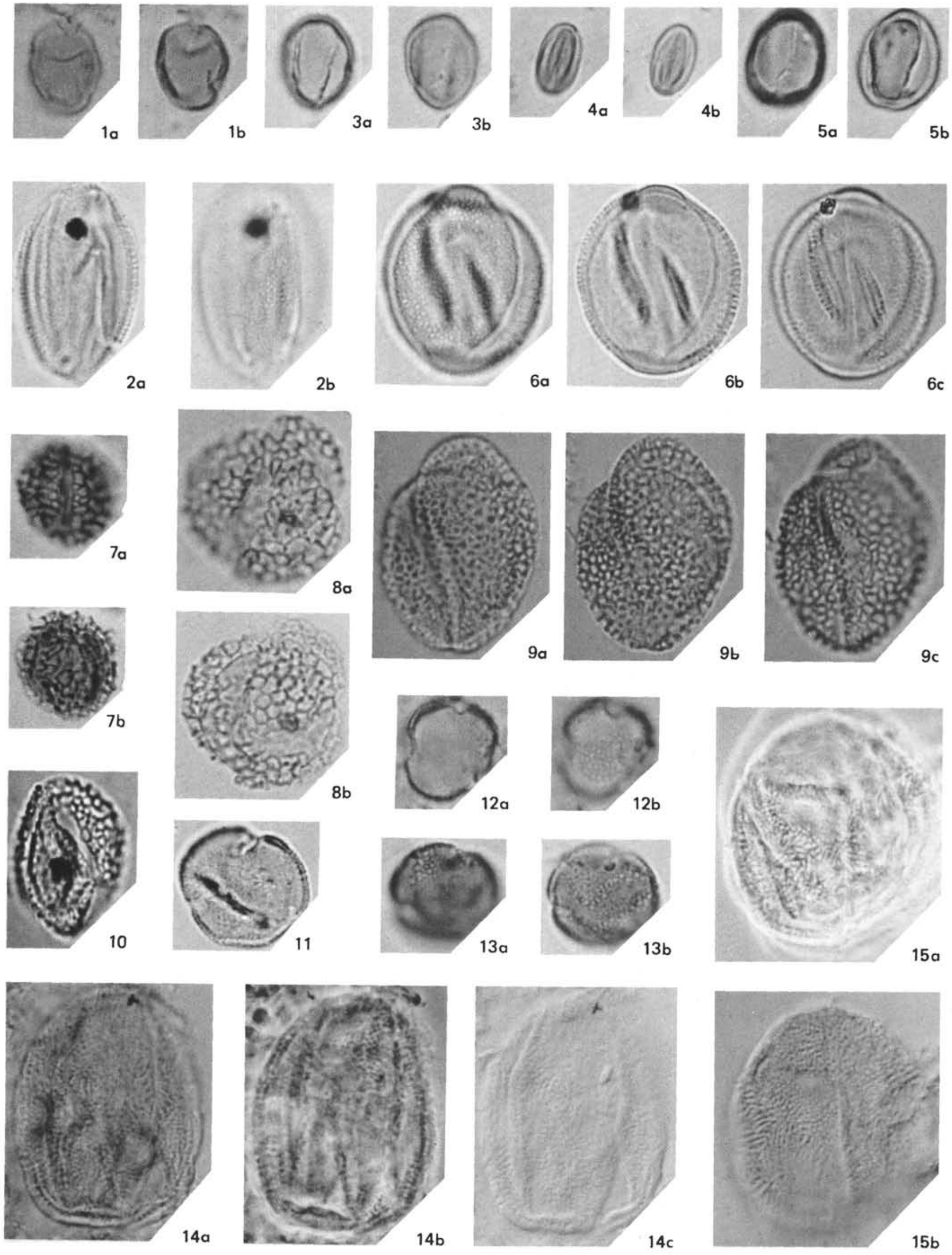


\section{PLATE 5}

All $\times 1000$ unless otherwise indicated

Figure 1a-c Striatopollis dubius. Sample 29-1, 43-44 cm.

Figure 2a-c Striatopollis dubius. Sample 29-2, 43-44 cm.

Figure 3 Tricolpites gigantoreticulatus. Sample 44-4, 36-38 $\mathrm{cm}$.

Figure $4 \quad$ Tricolpites parvus. Sample 24-2, 138-140 cm.

Figure $5 \quad$ Tricolpites parvus. Sample 44-4, 36-38 cm.

Figure 6 Tricolpites sp. cf. T. 326. Sample 29-2, 43-44 cm.

Figure 7 Tricolpites sp. CI. 13. Sample 24-2, 138-140 cm.

Figure 8a, b Tricolpites sp. S. CI. 175 bis. Sample 24-2, 138-140 $\mathrm{cm}$.

Figure 9a, b Tricolpites sp. cf. T. 260. Sample 40-5, 51-53 cm.

Figure 10a, b Tetrad of Tricolpites sp. S. CI. 260. Sample 40-5, $51-53 \mathrm{~cm}$.

Figure 11a, b Tricolpites sp. S. CI. 260 with suggestion of tricolporate structure. Sample 40-4, 35-37 cm.

Figure 12a, b Tricolpites parvus. Sample 40-5, 51-53 cm.

Figure 13a-c Tricolpites sp. S. CI. 326. Sample 24-2, 135-140 cm.

Figure 14a, b Tricolpites sp. S. CI. 326. Sample 24-2, 138-140 $\mathrm{cm}$. 


\section{PLATE 5}
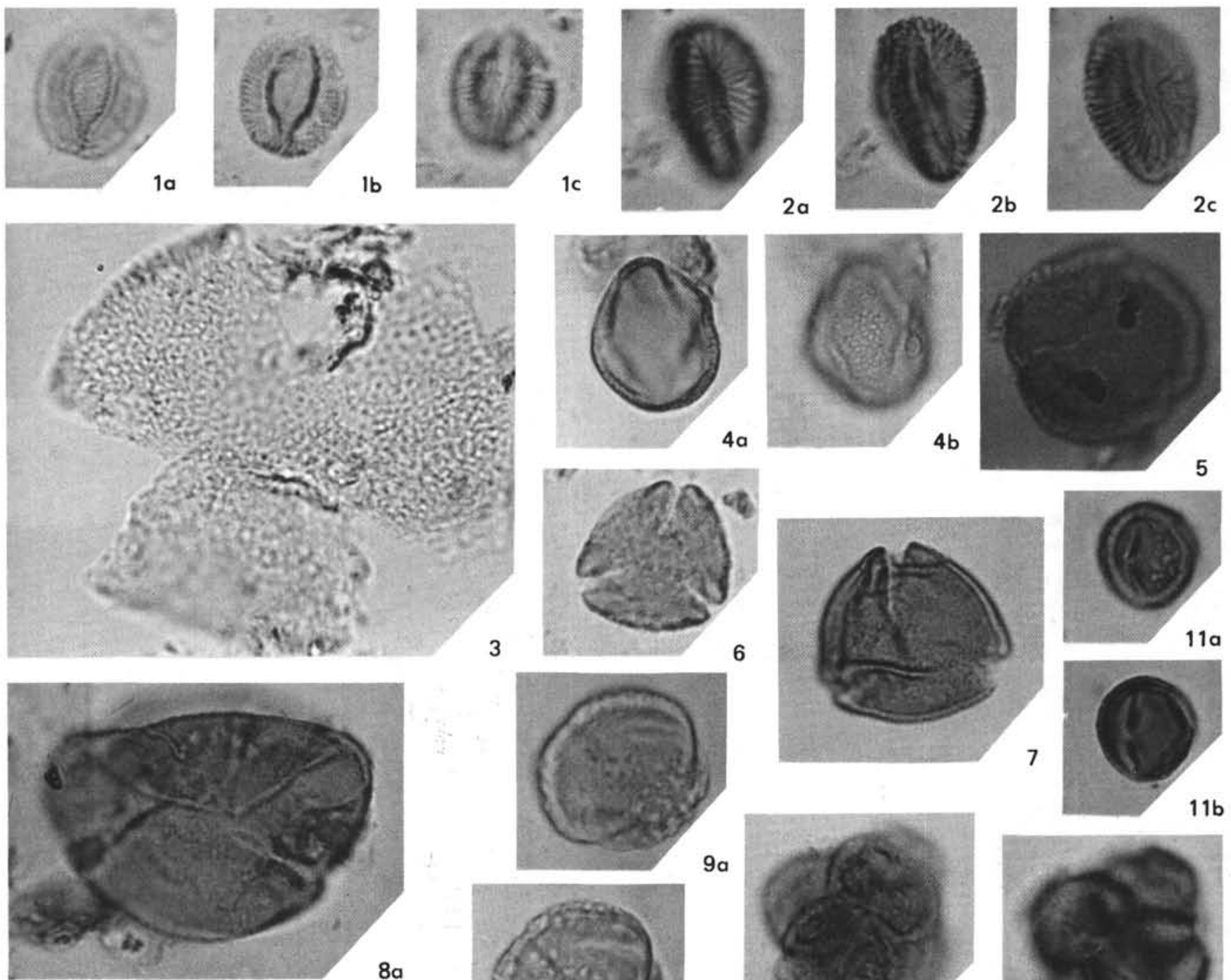

$8 a$
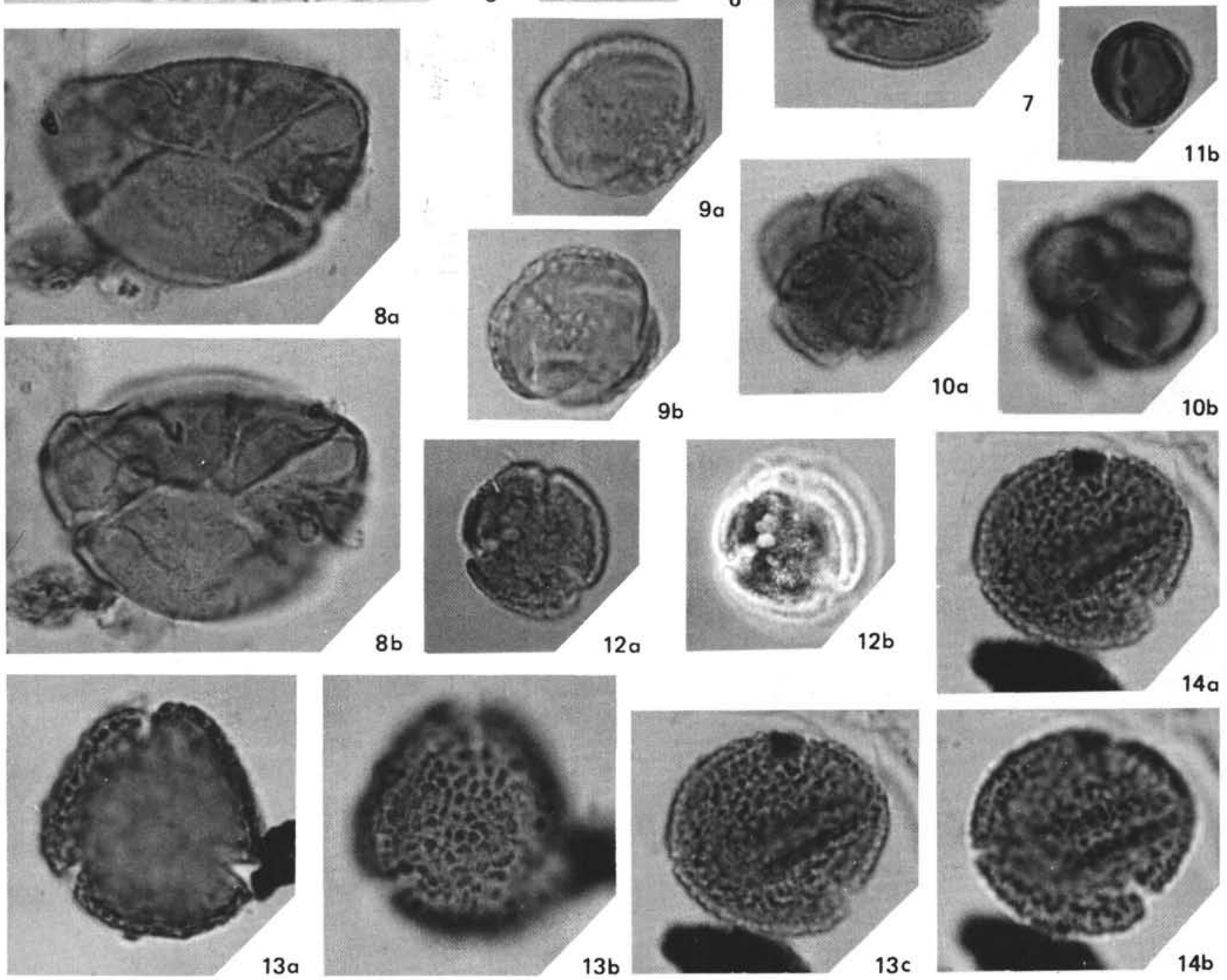

$10 \mathrm{~b}$

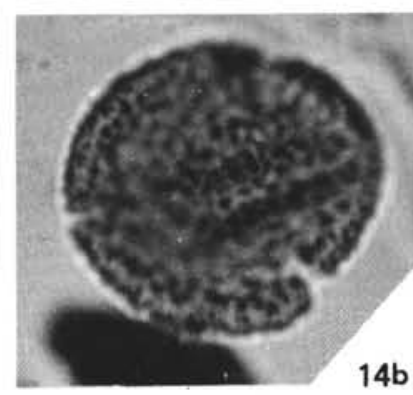


PLATE 6

All $\times 1000$ unless otherwise indicated

Figure 1a, b Tricolpites sp. A. Sample 40-4, 35-37 cm.

Figure 2a, b Tricolpites sp. A. Sample 40-5, 51-53 cm.

Figure 3 Tricolpites sp. D. Sample 29-2, 43-44 cm.

Figure 4a-d Tricolpites sp. D. Sample 29-2, 43-44 cm.

Figure 5a-c Tricolpites sp. E. Sample 24-2, 138-140 cm.

Figure 6 Tricolpites sp. E. Sample 24-2, 138-140 cm.

Figure 7 Tricolpites sp. B. Sample 29-2, 43-44 cm.

Figure 8a, b Tricolpites sp. C. Sample 29-2, 43-44 cm.

Figure 9a, b Tricolpites sp. G. Sample 24-2, 138-140 cm.

Figure 10 Tricolpites sp. F. Sample 23-4, 123-125 cm.

Figure 11a, b Tricolpites sp. F. Sample 25-3, 67-69 cm. 


\section{PLATE 6}
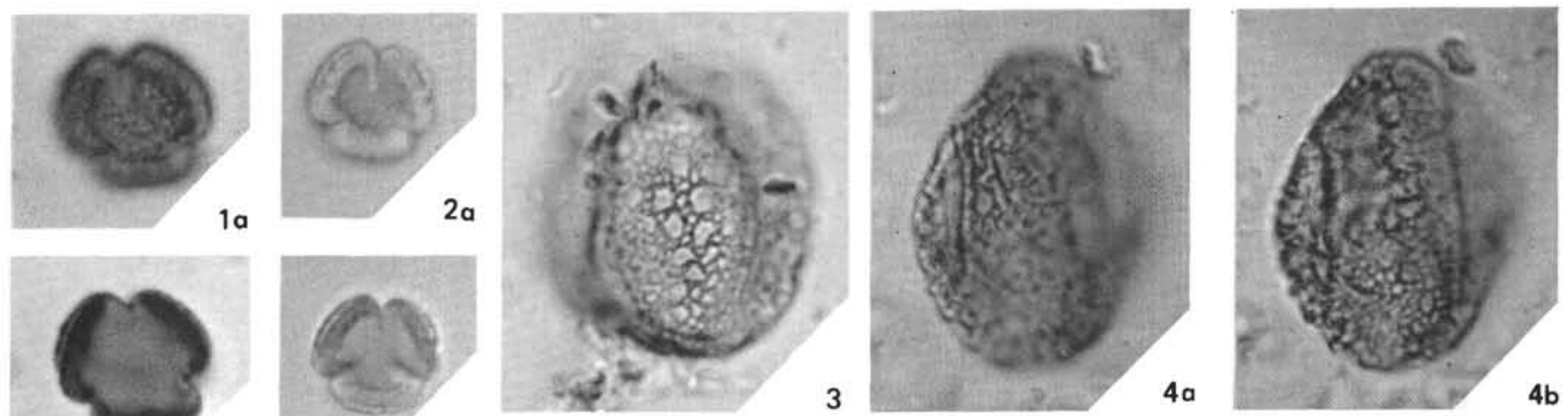

1b

$2 b$
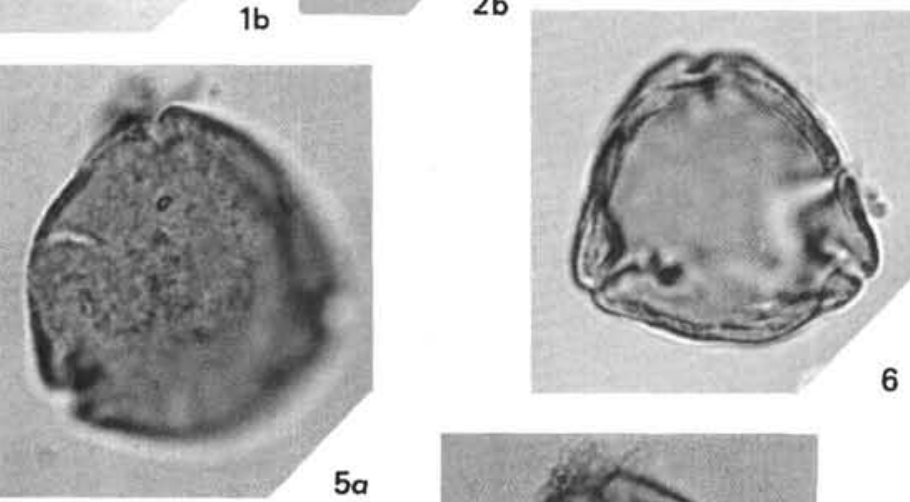

$5 a$
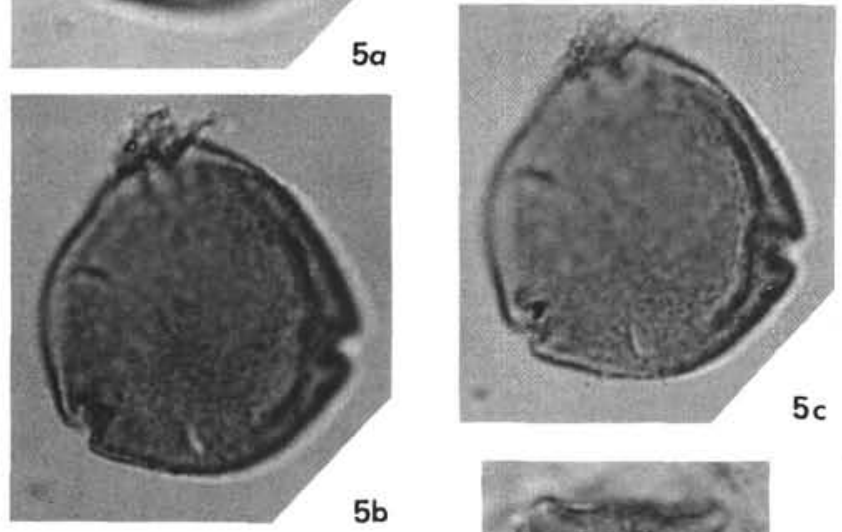

$5 b$
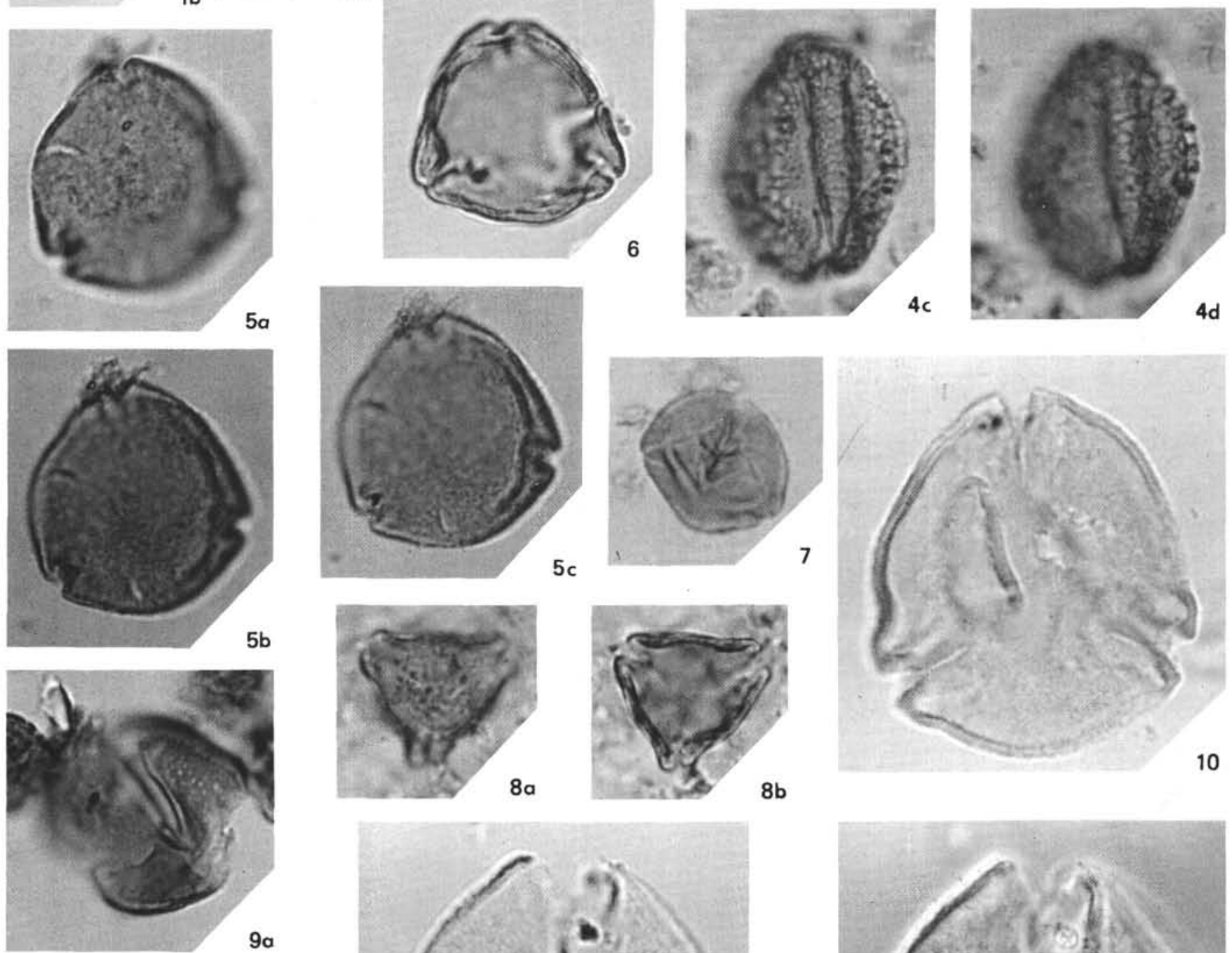

$5 c$

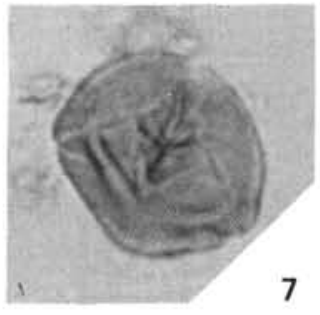

7

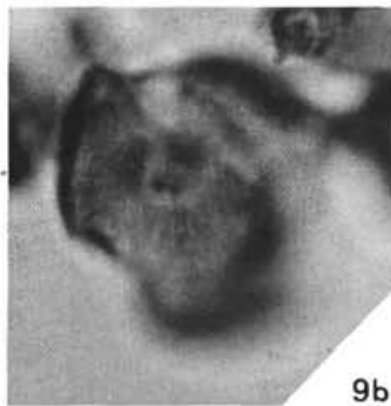

\section{a}

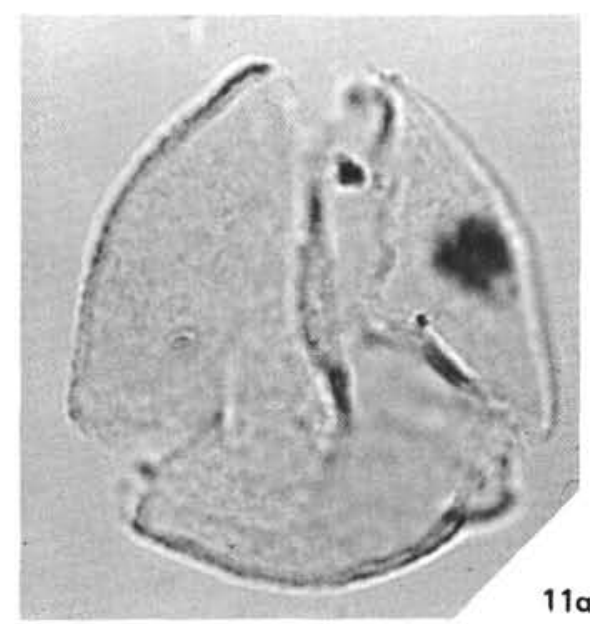

$8 b$

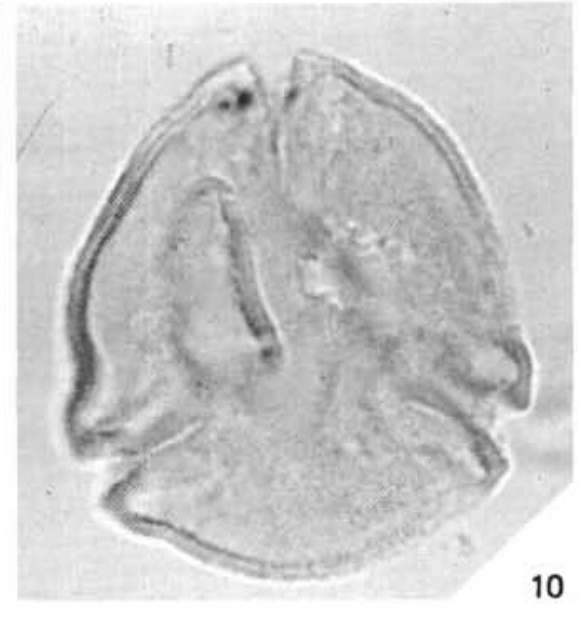

10

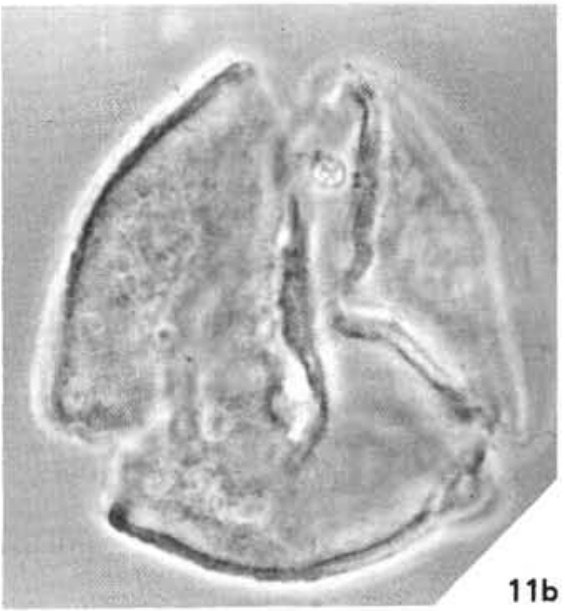




\section{PLATE 7}

All $\times 1000$ unless otherwise indicated

Figure 1a, b Tricolpites sp. H. Sample 23-4, 123-125 cm.

Figure 2a-c Tricolpites sp. I. Sample 23-4, 123-125 cm.

Figure 3 Tricolpites sp. I. Sample 23-4, 123-125 cm.

Figure 4a, b Tricolpites sp. J. Sample 23-4, 123-125 cm.

Figure 5a-c Liliacidites sp. Sample 29-2, 43-44 cm.

Figure $6 \quad$ Liliacidites dividuus. Sample 40-5, $51-53 \mathrm{~cm}$.

Figure 7a, b Liliacidites textus. Sample 29-3, 43-44 cm.

Figure 8a, b Liliacidites inaequalis. Sample 40-5, 51-53 cm.

Figure 9a, b Trifossapollenites ivoirensis. Sample 40-4, 35-37 $\mathrm{cm}$. 
PLATE 7
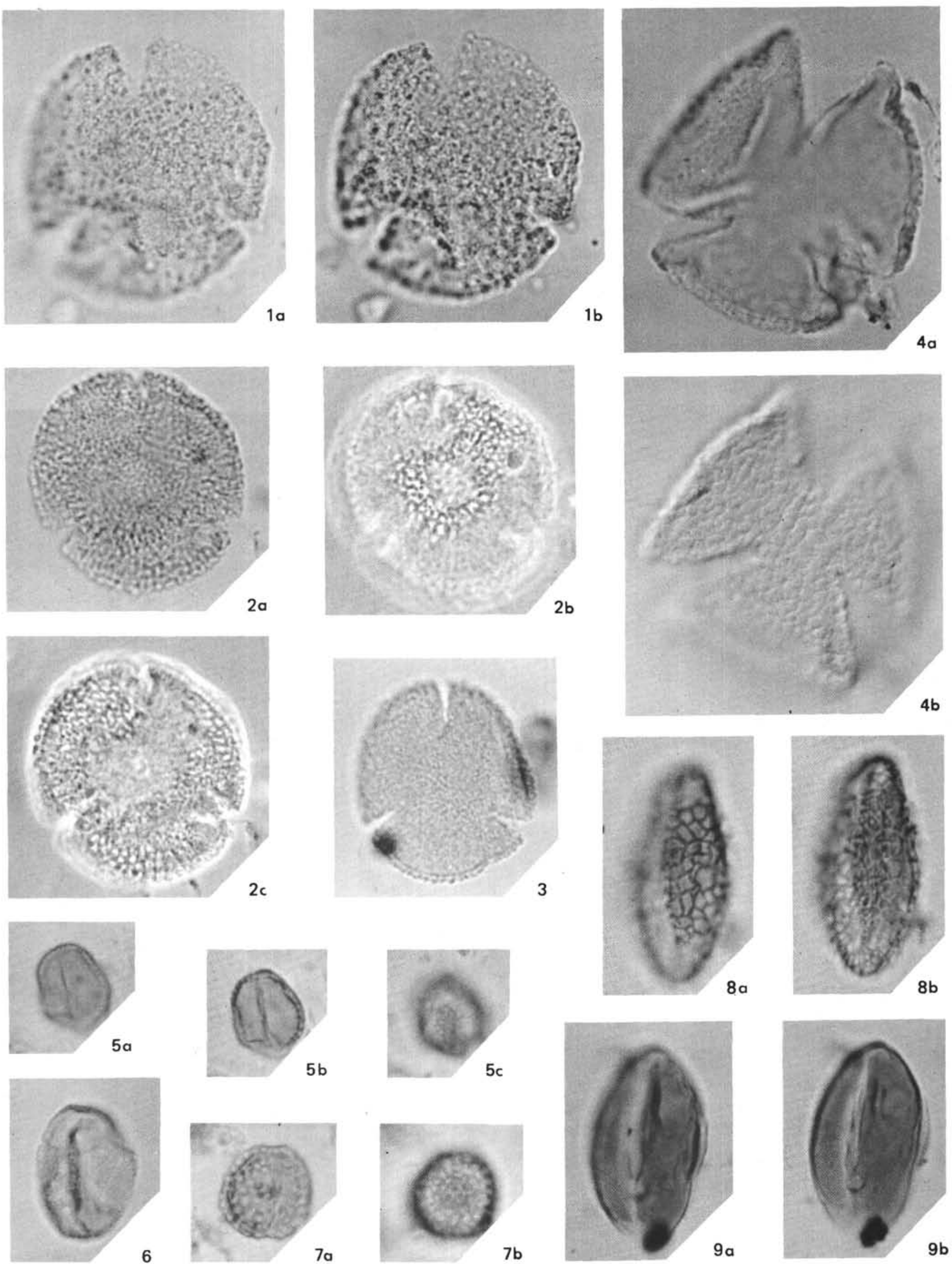
PLATE 8

All $\times 1000$ unless otherwise indicated

Figure 1 Cretacaeiporites scabratus. Sample 24-2, 138-140 $\mathrm{cm}$.

Figure 2a, b Cretacaeiporites aff. scabratus. Sample 23-4, 123$125 \mathrm{~cm}$.

Figure 3a, b Cretacaeiporites polygonalis. Sample 23-4, 123-125 $\mathrm{cm}$.

Figure 4 Cretacaeiporites mulleri. Sample 24-2, 138-140 cm.

Figure 5a-c Triorites sp. A. Sample 24-2, 138-140 cm.

Figure 6a, b Cretacaeiporites aff. scabratus. Sample 23-4, 123$125 \mathrm{~cm}$.

Figure 7a, b Hexaporotricolpites emelianovi. Sample 24-2, 138$140 \mathrm{~cm}$.

Figure 8a, b Hexaporotricolpites emelianovi. Sample 29-2, 43-44 $\mathrm{cm}$.

Figure 9a, b Hexaporotricolpites coronatus. Sample 24-2, 138$140 \mathrm{~cm}$. 
PLATE 8
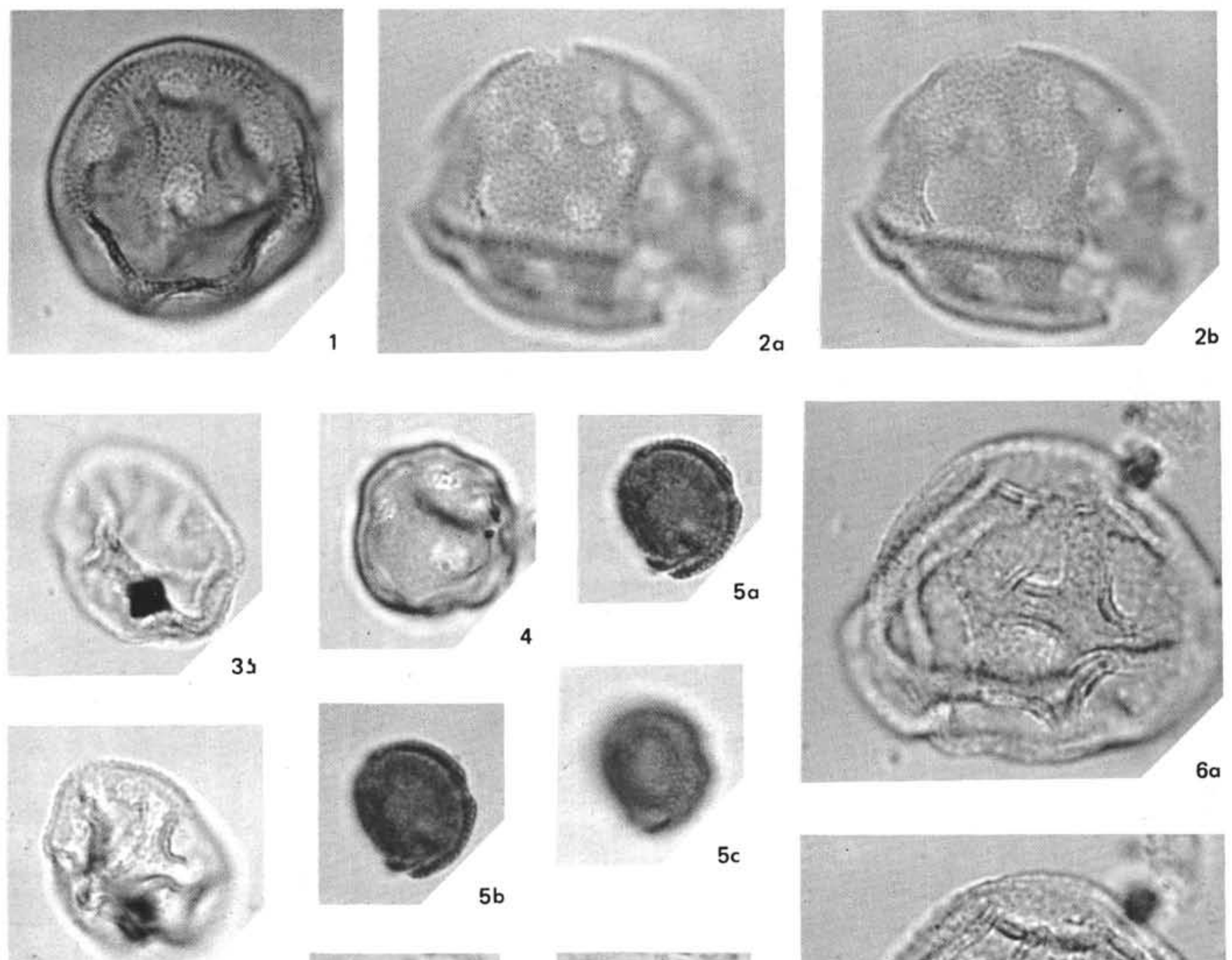

$5 c$
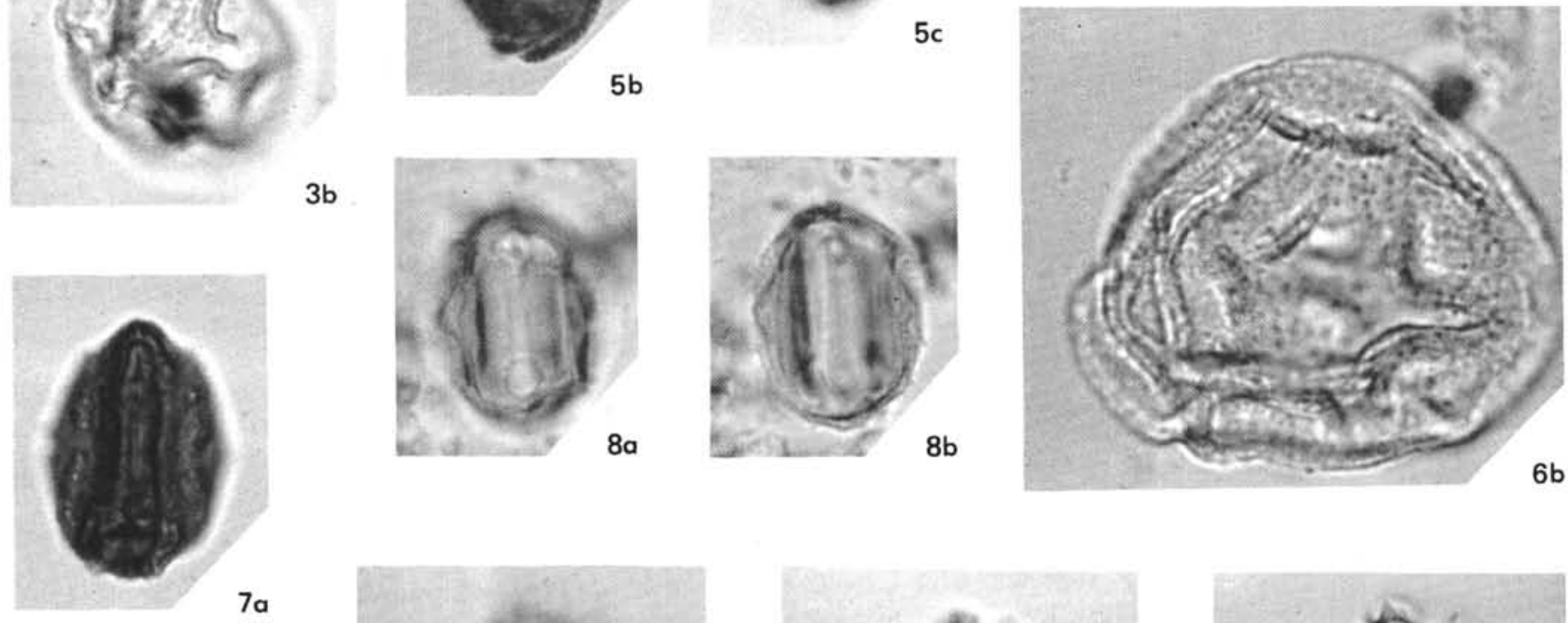

$3 b$
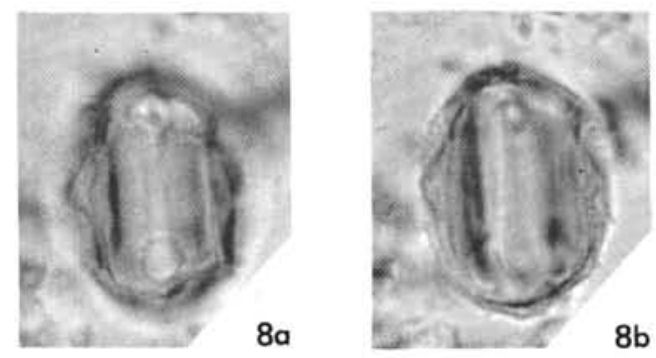

$6 b$
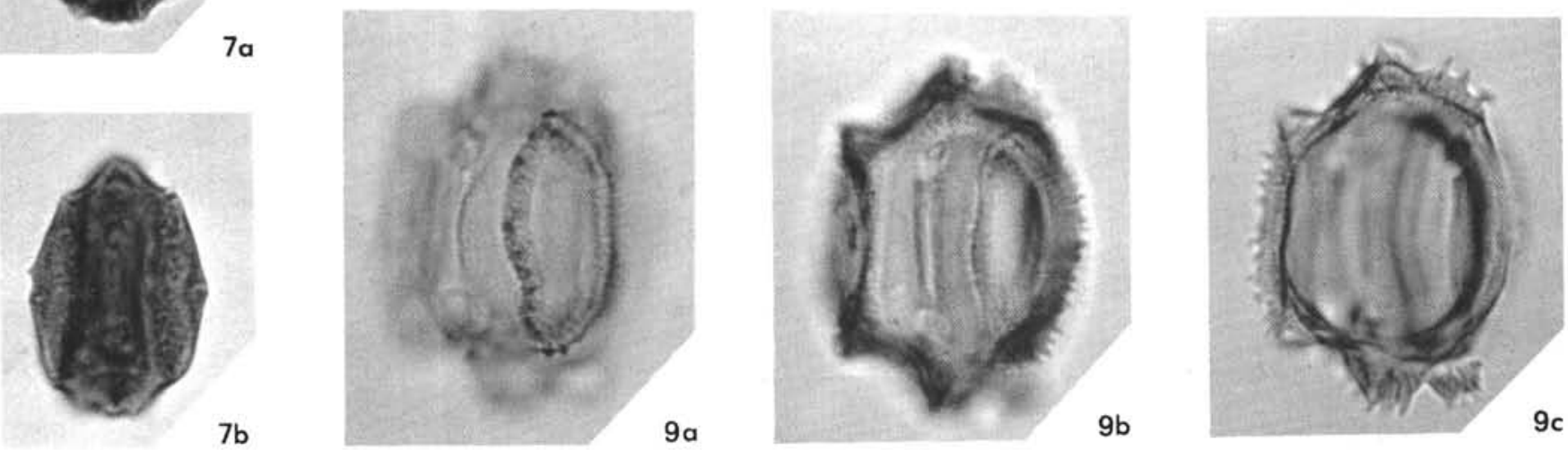


\section{PLATE 9}

All $\times 1000$ unless otherwise indicated

Figure 1a-c Hexaporotricolpites potoniei. Sample 24-2, 138-140 $\mathrm{cm}$.

Figure 2a, b Syncolporites form B S.CI. 146. Sample 24-2, 138$140 \mathrm{~cm}$.

Figure 3a, b Syncolporites form B S.CI. 146. Sample 24-2, 138$140 \mathrm{~cm}$.

Figure 4a, b Syndemicolpites sp. A. Sample 23-3, 128-130 cm.

Figure 5 Syndemicolpites $\mathrm{sp}$. A. Sample 23-4, 123-125 cm.

Figure 6 Bulbopollis sp. Sample 23-4, 123-125 cm.

Figure $7 \quad$ Fungal Spore. Sample 44-4, 36-38 cm

Figure 8 Incertae Sedis sp. A. Sample 29-2, 43-44 cm.

Figure 9a, b Reticulatasporites jardinus. Sample 44-4, 36-38 cm. 


\section{PLATE 9}
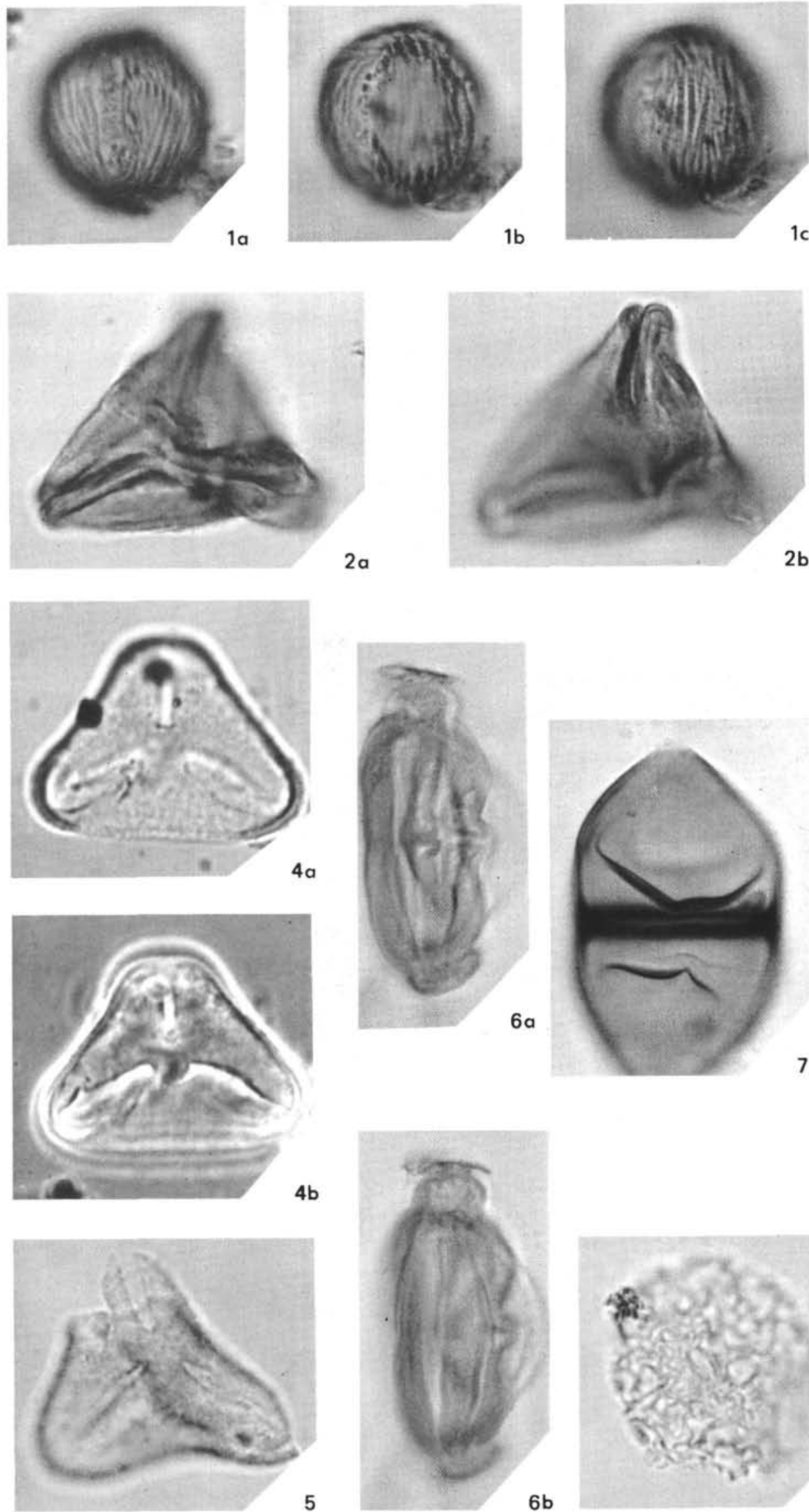

$2 b$

$1 c$
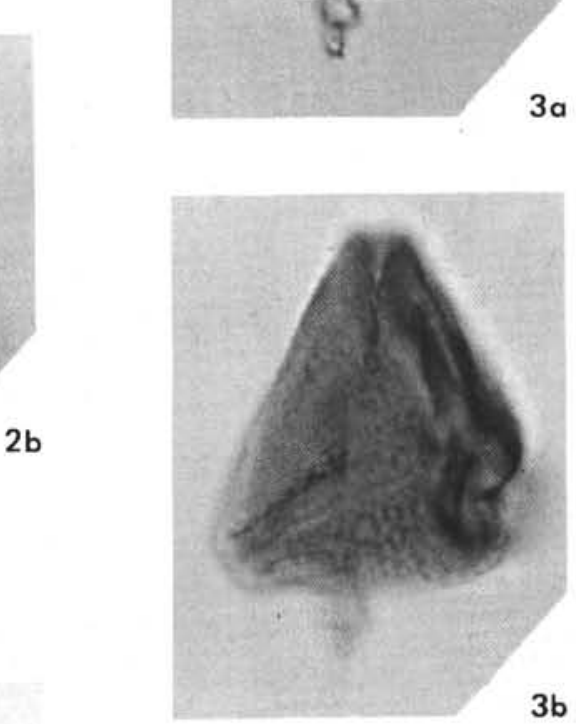

3b
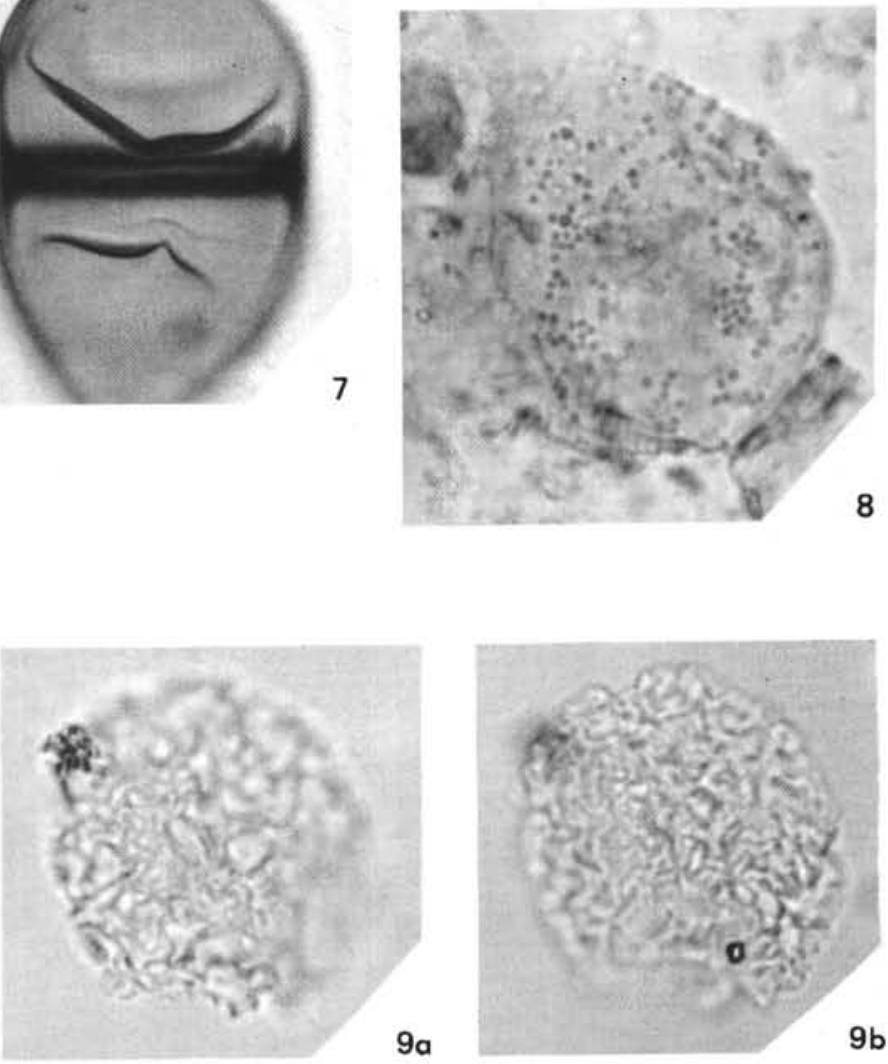
PLATE 10

All $\times 1000$ unless otherwise indicated

Figure 1a, b Ascodinium acrophorum. Sample 25-3, 67-69 cm.

Figure 2 Ascodinium acrophorum. Sample 25-3, 67-69 cm.

Figure 3 Cyclonephelium distinctum. Sample 24-2, 138-140 $\mathrm{cm}$.

Figure 4a, b Deflandrea acuminatum. Sample 23-4, 123-125 cm.

Figure 5 Dinogymnium euclaensis. Sample 23-3, 128-130 $\mathrm{cm}$.

Figure 6a, b Dinogymnium euclaensis. Sample 23-4, 123-125 $\mathrm{cm}$.

Figure 7a, b Dinogymnium acuminatum. Sample 23-4, 123-125 $\mathrm{cm}$.

Figure 8a, b Dinogymnium acuminatum. Sample 23-4, 123-125 $\mathrm{cm}$. 
PLATE 10
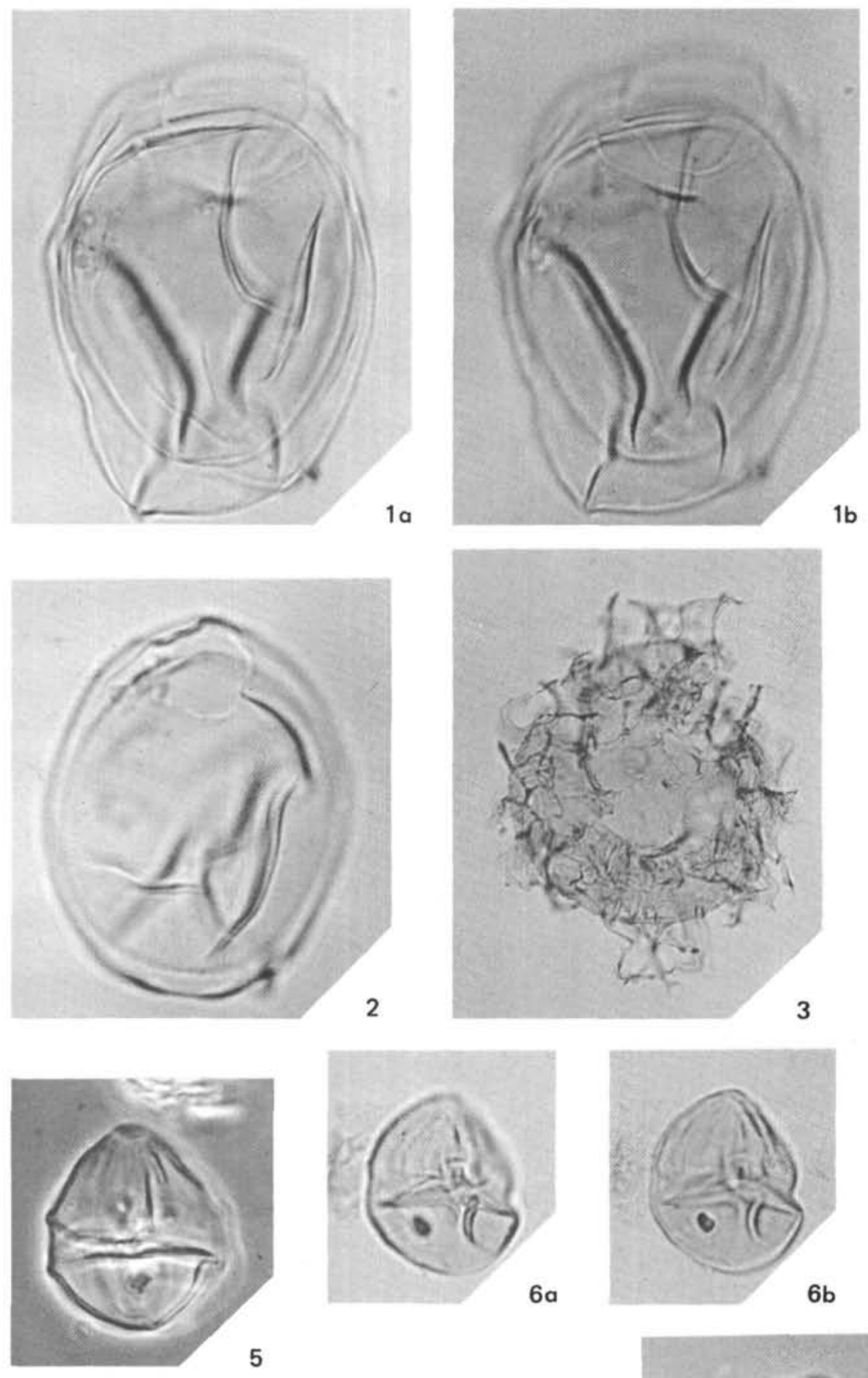

5
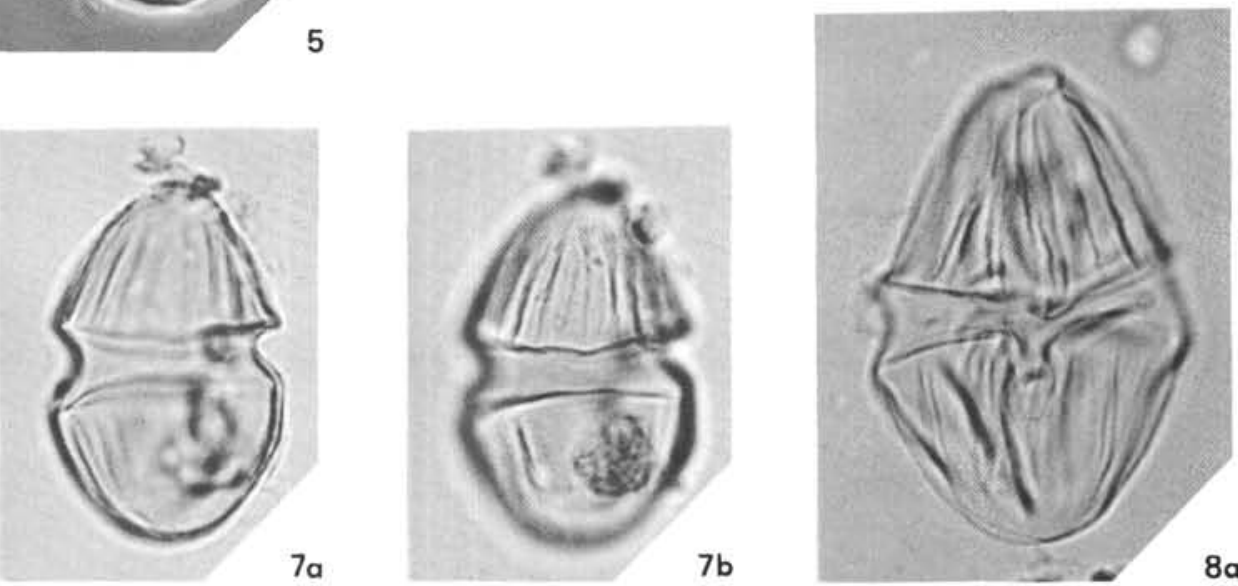
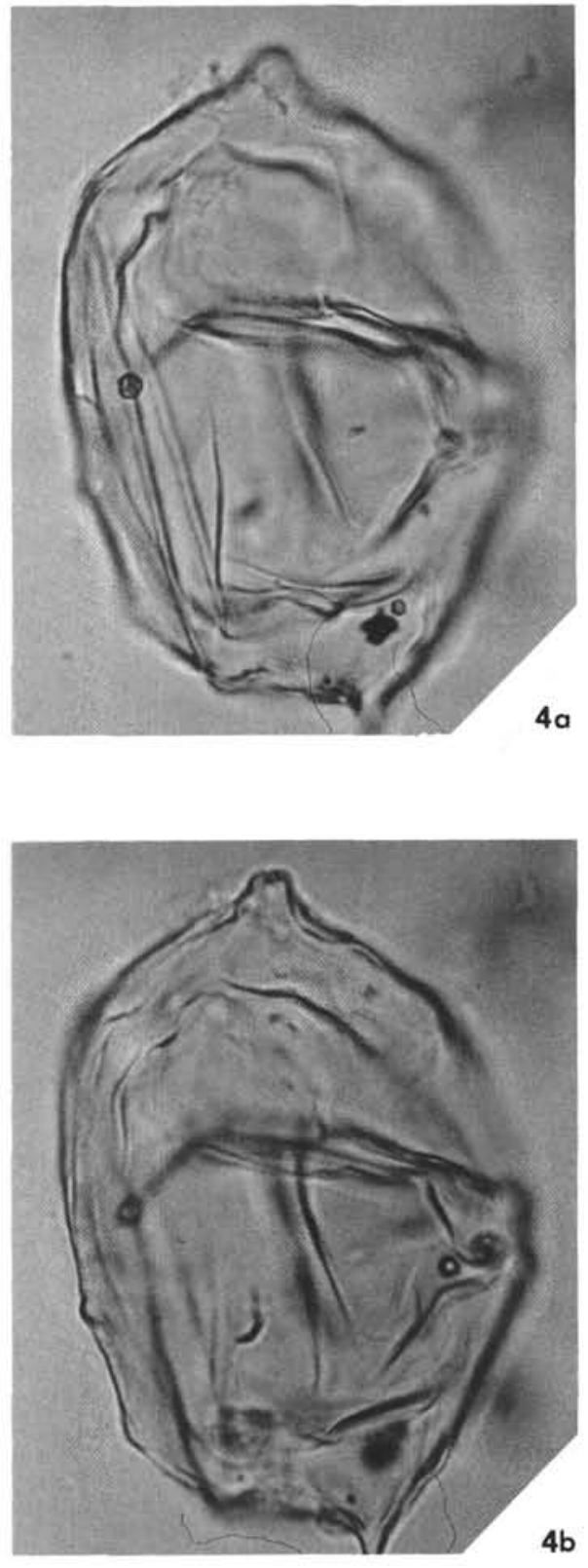

$8 a$

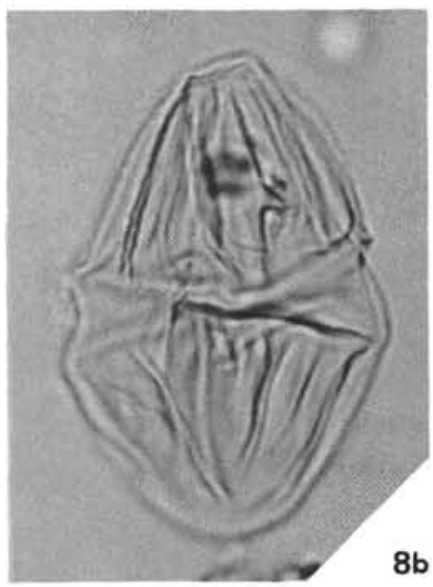


PLATE 11

All $\times 1000$ unless otherwise indicated.

Figure 1 Dioxya villosa. Sample 40-5, $51-53 \mathrm{~cm}$.

Figure 2a, b Hystrichosphaeridium arundum. Sample 40-4, 35$37 \mathrm{~cm}$.

Figure 3a-c Leptodinium sp. A. $\times 400$. Sample $44-4,36-38 \mathrm{~cm}$.

Figure 4a-c Leptodinium sp. A. $\times 400$. Sample 44-4, 36-38 cm.

Figure 5a, b Leptodinium sp. Sample 44-4, 36-38 cm.

Figure 6a, b Litosphaeridium conispinum. Sample 29-2, 43-44 cm.

Figure 7 Litosphaeridium siphoniphorum. Sample 24-2, 138$140 \mathrm{~cm}$. 
PLATE 11
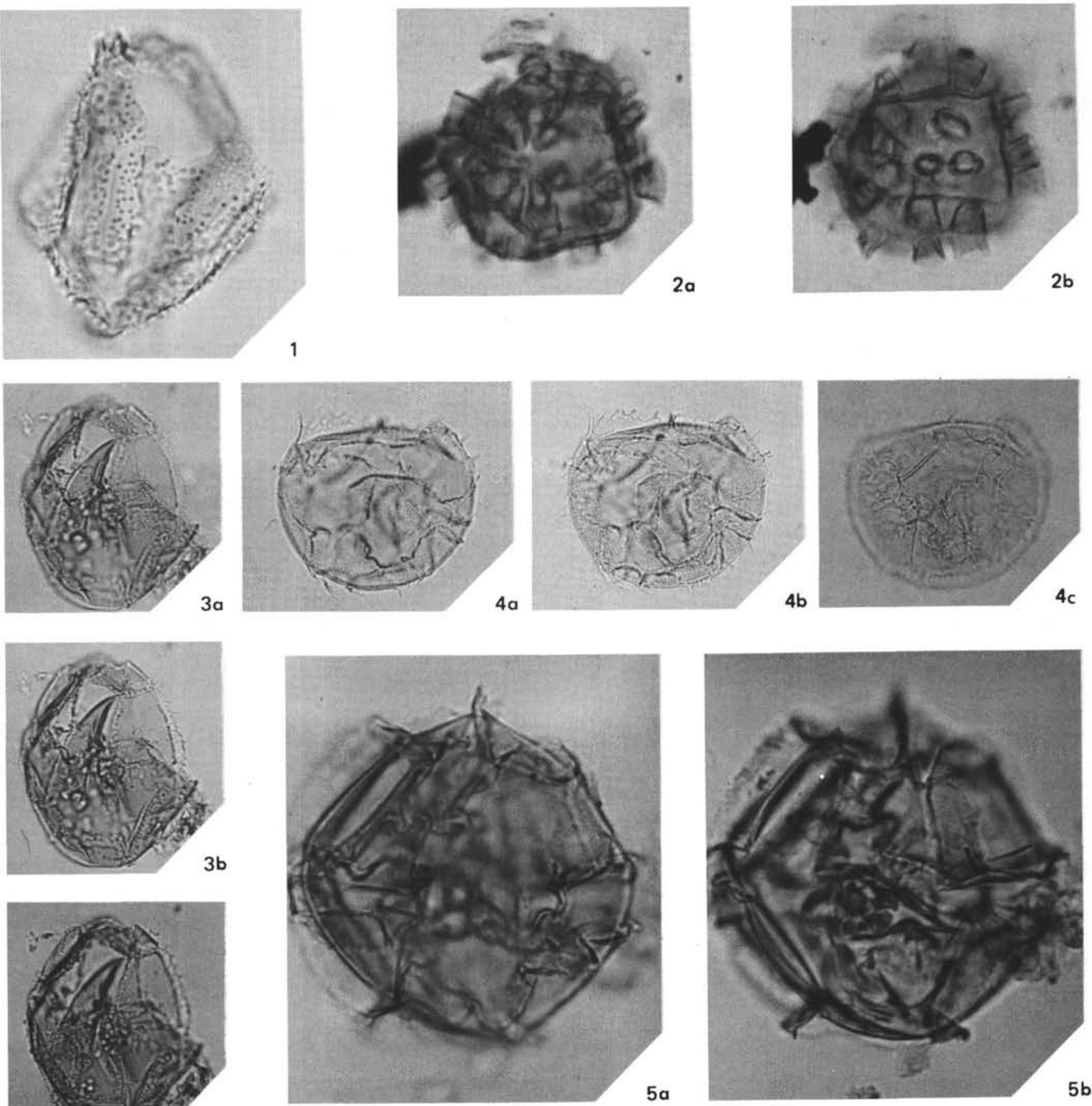

$3 c$
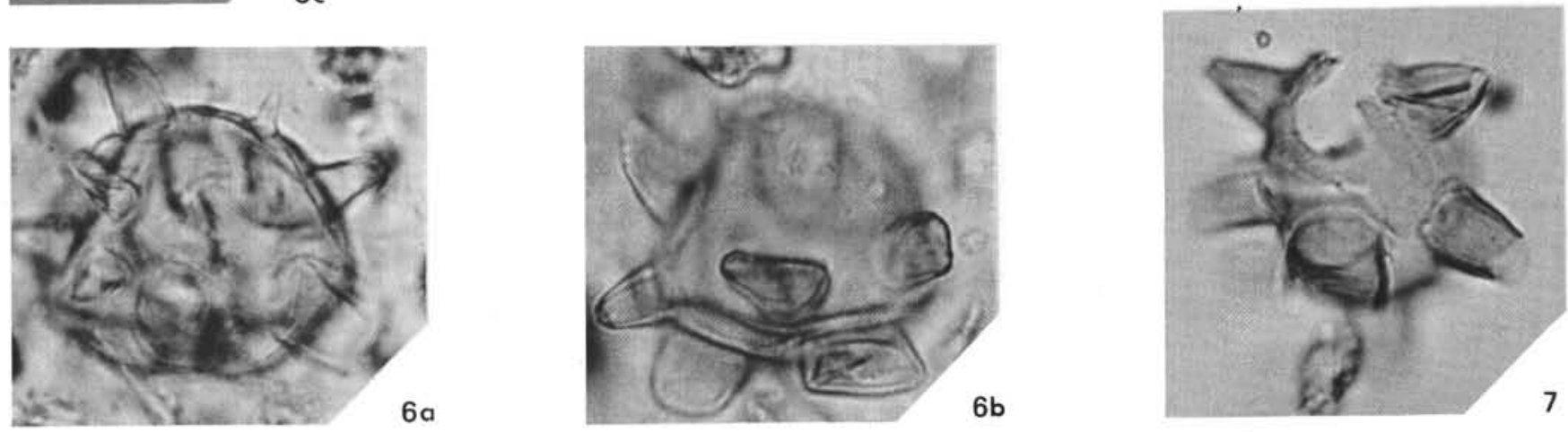
PLATE 12

All $\times 1000$ unless otherwise indicated

Figure 1 Oligosphaeridium complex, $\times 400$. Sample 44-4, 36$38 \mathrm{~cm}$.

Figure 2 Palaeohystrichophora infusorioides. Sample 24-2, $138-140 \mathrm{~cm}$.

Figure 3a, b Spiniferites sp. Sample 23-4, 123-125 cm.

Figure 4a, b $\quad$ Subtilisphaera cf. $S$. perlucida. Sample 45-2, 118$119 \mathrm{~cm}$.

Figure 5a, b Subtilisphaera cf. $S$. perlucida. Sample 45-2, 118$119 \mathrm{~cm}$.

Figure 6 Pterospermella sp. Sample 25-3, 67-69 cm.

Figure 7 Micrhystridium sp. Sample 40-4, 35-37 cm.

Figure $8 \quad$ Micrhystridium sp. Sample 24-2, 138-140 cm.

Figure 9a, b Cymatiosphaera sp. A. Sample 25-3, 67-69 cm.

Figure 10a, b Crassosphaera concinna. Sample 25-3, 67-69 cm. 
PLATE 12
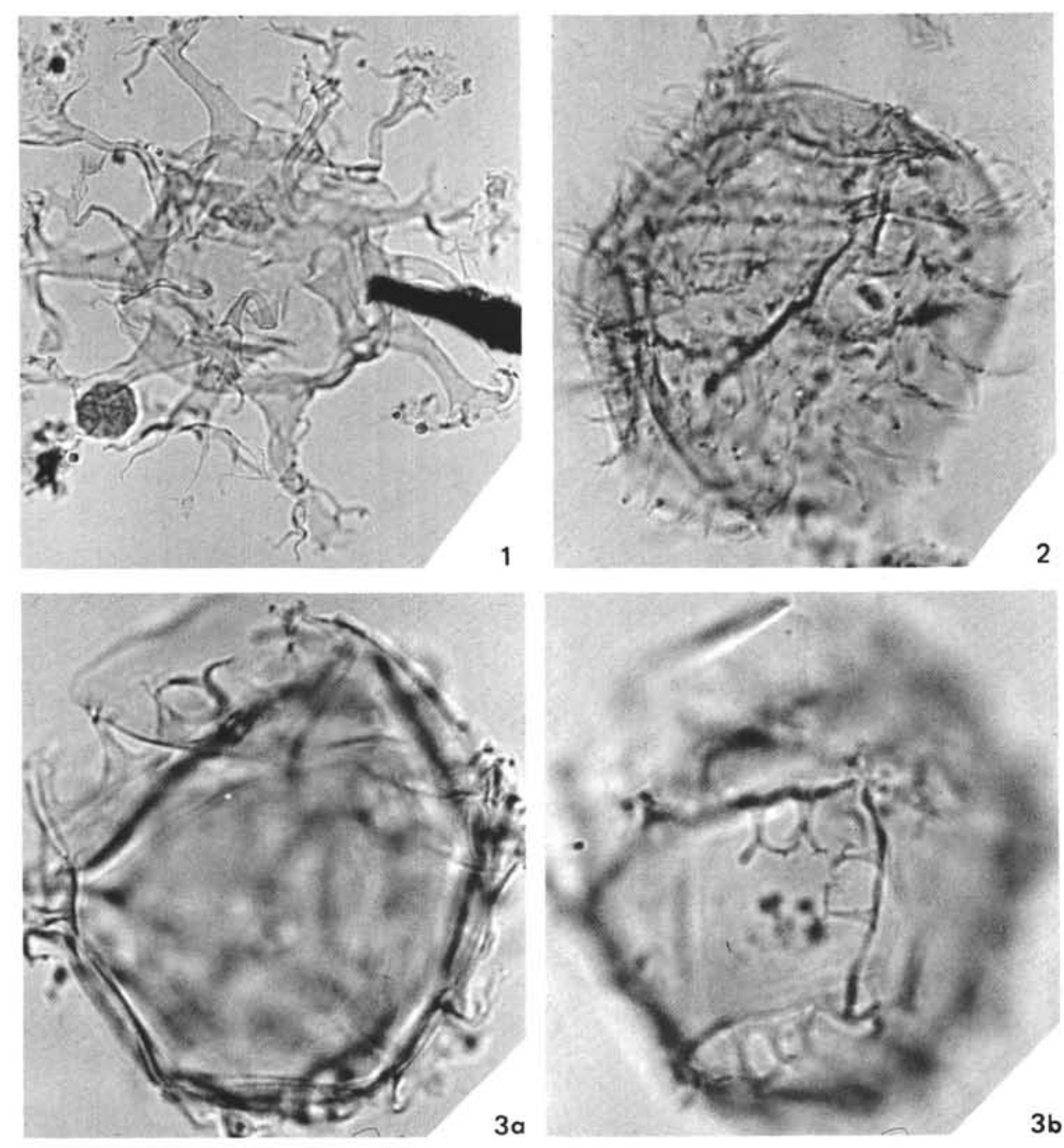
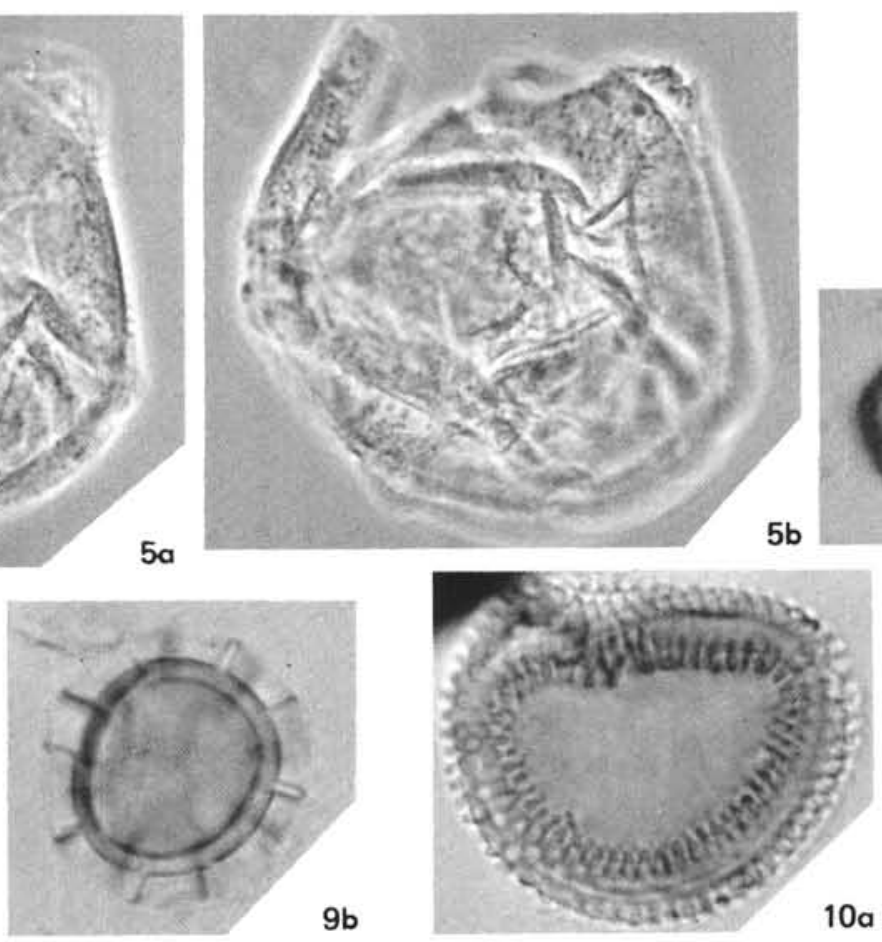
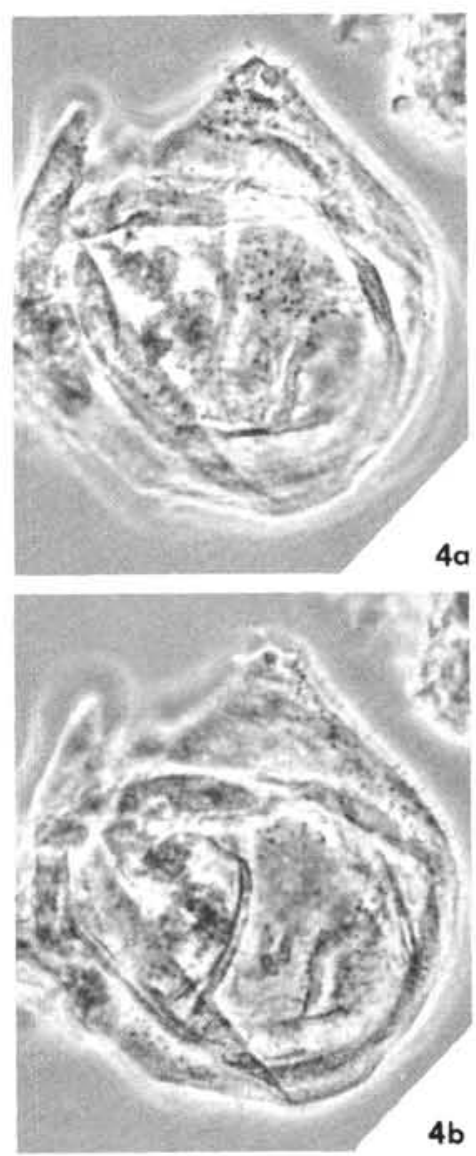

$3 b$

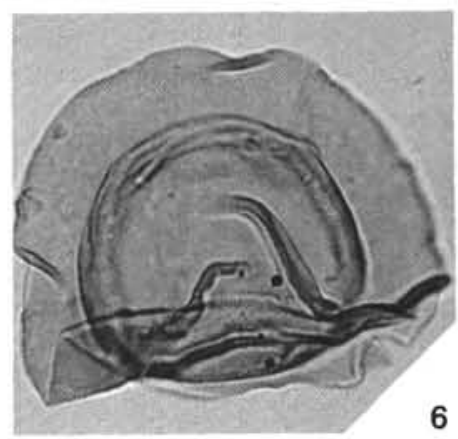

6

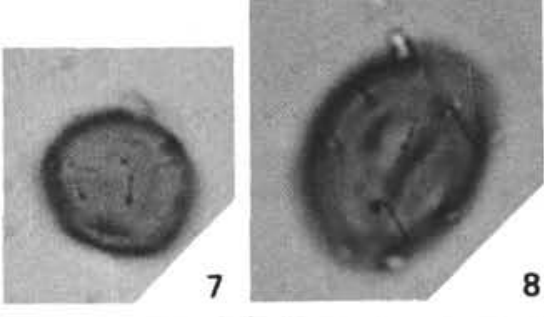

8

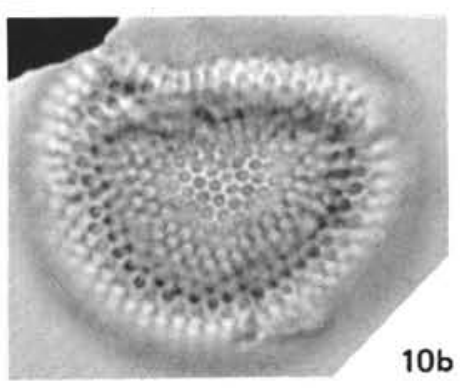

